\title{
CONDOMINIUM AND COOPERATIVE HOUSING: TRANSACTIONAL EFFICIENCY, TAX SUBSIDIES, AND TENURE CHOICE
}

\author{
HENRY HANSMANN*
}

\section{INTRODUCTION}

$\mathrm{T}$ WENTY-FIVE years ago, cooperative apartment buildings were uncommon in the United States, and condominiums were virtually nonexistent. Since then, however, both forms, and particularly condominiums, have spread rapidly through the real estate market. This article explores the factors responsible for this development. In the process, it also assesses the relative transactional efficiency of consumer ownership and investor ownership in multiunit housing.

I argue that two factors appear principally responsible for the recent spread of cooperatives and condominiums. First is the large tax subsidy to owner-occupied housing that has existed since the Second World War and that has been particularly large during the past two decades. Second is innovation in the forms available for organizing ownership in multiunit dwellings. A variety of considerations suggest that the first of these factors has been more important than the second and that, in the absence of the tax subsidy, cooperatives and condominiums would occupy a much smaller share of the housing market than they do at present. In support of this analysis, this article offers the first sophisticated calculations of the magnitude of the pure tax subsidy to owner-occupied housing, as

\footnotetext{
* Professor of Law, Yale University. Generous research support was provided by the John Simon Guggenheim Memorial Foundation and the Yale Law School. Special thanks are due to Alan Gerber and Lucy Allen for research assistance. Helpful comments on earlier drafts were provided by Lucian Bebchuk, Robert Ellickson, Patrick Hendershott, John Quigley, Susan Rose-Ackerman, Ruth Wedgwood, and participants in workshops at Georgetown University, Harvard, Stanford, the University of Chicago, and the University of Virginia law schools.
}

[Journal of Legal Studies, vol. XX (January 1991)]

(C) 1991 by The University of Chicago. All rights reserved. 0047-2530/91/2001-0003\$01.50 
opposed to rental housing, and of the changes in that subsidy over the past fifty years.

Section II briefly surveys the essential characteristics and recent evolution of housing cooperatives and condominiums. Section III analyzes the principal factors governing the transactional efficiency of cooperatives and condominiums as opposed to rental housing. Section IV discusses the tax treatment of cooperatives and condominiums and provides quantitative estimates of the net tax subsidy to these forms at different points over the past fifty years. Section $V$ considers the influence of rent control, increasing liquidity of apartment residents, and mortgage insurance on the temporal evolution of cooperatives and condominiums. Section VI assesses the significance of organizational innovation in the forms of tenure for multiunit buildings. Section VII examines the conspicuous paucity of commercial cooperatives and condominiums. Section VIII explores implications for organizational efficiency and tax policy, and Section IX concludes.

Today the condominium form has spread to a number of different configurations of housing construction and occupancy, including time-shared resort lodging and groups of detached single-family dwellings sharing common amenities. In the discussion here, however, primary attention will be given to multiunit apartment buildings, which were the original focus for cooperative and condominium housing and which remain the context in which these forms are principally employed.

\section{An Overview of the Organization and Evolution of Housing CoOperatives and Condominiums}

In a housing cooperative, the occupants of the building lease their individual units. The arrangement is distinguished from an ordinary landlord-tenant relationship by the fact that the tenants collectively own the building by holding shares in a corporation that has title to the property. Thus, the tenants are collectively their own landlord. In a condominium, in contrast, the occupants each own the individual units they occupy. There remains an element of collective ownership in the condominium, but it is confined to the common elements of the property such as the hallways, elevators, exterior shell, roof, and grounds.

One consequence of this distinction is that mortgage financing in a cooperative is generally obtained collectively by the cooperative corporation with a single blanket mortgage for the building as a whole, while in a condominium each unit owner obtains his own mortgage financing with only his individual unit pledged as security. In most other essential operational respects, the two forms are not notably different. In particular, the 
lease in a typical cooperative is a "proprietary lease" entitling the lessee to perpetual occupany of the unit. The lease, and the associated shares of stock in the cooperative corporation, can be sold by the lessee at whatever price the market will bring. Thus a member of a cooperative, like the owner of a condominium, effectively has a perpetual, exclusive, and freely transferable ${ }^{1}$ property right in the physical unit he occupies. The term "owner-occupancy" will therefore be used here to encompass both forms.

In the United States, cooperatives long antedate condominiums. New York City's first cooperative apartment building, and perhaps the first in the United States, was built in $1876 ;^{2}$ by 1929 the city contained at least 125 cooperative apartment buildings, most of which were luxury buildings. ${ }^{3}$ Cooperative apartments also spread to other American cities during this period; ${ }^{4}$ Chicago, for example, had over 100 cooperative apartment buildings by $1930 .^{5}$

There are no accurate figures on the numbers of cooperatives in existence between 1930 and 1975. However, an estimate for 1960, which may be generous, suggests that there may have been as many as 150,000 cooperative units in existence then, amounting to roughly 1 percent of all multifamily dwellings; about one-third of these units were in New York City. ${ }^{6}$ Table 1 gives total housing stock data for cooperatives since 1975, when systematic data first became available; as shown there, the

I Subject, however, to approval by the managing board in the case of a cooperative. See note 15 infra.

2 Cooperative Homes Old to Manhattan, New York Times, January 27, 1929, sec. 12, at 1, col. 8. At least thirty more cooperative apartment buildings appear to have been constructed in New York City before the First World War. Id.; New York Times, February 10, 1907, at 16, col. 5; New York Times, April 25, 1909, sec. 7, at 2, col. 1.

3 Twentieth Century Fund, American Housing: Problems and Prospects 233 (1944); New York Times, January 25, 1929, sec. 12, at 1, col. 6. By the 1920 s there were also some lowerand middle-income cooperative apartment buildings, a number of which were sponsored by unions. Burr Henly, Financing Housing Cooperatives 71-84 (unpublished master's thesis, Univ. Washington, 1982). Low-income cooperatives still exist; their principal role, however, is to assure that housing subsidies are passed through to tenants; absent subsidies they would probably be rare.

${ }^{4}$ Otis Castle, Legal Phases of Cooperative Buildings, 2 So. Cal. L. Rev. 1 (1928); Twentieth Century Fund, supra note 3.

${ }^{5}$ Chester McCullough, Cooperative Apartments in Illinois, 26 Chi.-Kent L. Rev. 303, 305 (1948).

${ }^{6}$ Foundation for Cooperative Housing, Cooperative Development with Federal Assistance, in Housing - the Cooperative Way 226 (Jerome Liblit ed. 1964); International Labor Office (Geneva), Housing Cooperatives 108 (1964). There were 13.8 million multifamily housing units in 1960. U.S. Dep't of Commerce, Statistical Abstract of the United States, 1988, at 688, table 1221 (1987). 
TABLE 1

Composition of Multifamily Housing Stock, 1975-83 (in Thousands of Units)

\begin{tabular}{lccccccc}
\hline \hline & $\begin{array}{c}\text { Total } \\
\text { Multifamily }\end{array}$ & Rental & Co-op & \% Co-op & Condo & \% Condo & $\begin{array}{c}\text { \% Co-op } \\
\text { and Condo }\end{array}$ \\
\hline 1975 & 17,572 & 16,704 & 361 & 2.1 & 597 & 2.9 & 4.9 \\
1976 & 18,022 & 16,983 & 405 & 2.2 & 634 & 3.5 & 5.8 \\
1977 & 18,625 & 17,616 & 344 & 1.8 & 665 & 3.6 & 5.4 \\
1978 & 19,162 & 17,949 & 348 & 1.8 & 865 & 4.5 & 6.3 \\
1979 & 19,407 & 18,099 & 341 & 1.8 & 967 & 5.0 & 6.7 \\
1980 & 19,672 & 18,269 & 313 & 1.6 & 1,090 & 5.5 & 7.1 \\
1981 & 20,641 & 18,961 & 409 & 2.0 & 1,271 & 6.2 & 8.1 \\
1983 & 21,331 & 19,582 & 360 & 1.7 & 1,389 & 6.5 & 8.2 \\
\hline
\end{tabular}

Source.-U.S. Dep't of Housing and Urban Development, Annual Housing Survey: 1983, Part A. General Housing Characteristics (Current Housing Reports ser. H-150-83 (1984)).

market share of cooperatives evidently reached its peak in 1976, when cooperatives accounted for 2.2 percent of all multiunit housing.

As Table 1 also shows, in the 1970s the condominium form replaced the cooperative as the preferred device for owner-occupancy of apartment buildings in most of the country. New York City is the only significant jurisdiction where new cooperatives have remained an important part of the market. ${ }^{7}$

Prior to 1961, no American state had enacted enabling legislation for housing condominiums. For this reason, and because condominiums were quite awkward (though not impossible) to fashion with the devices of common-law conveyancing, almost no condominium housing was created in the United States before then. Between 1961 and 1963, however, thirty-four states enacted enabling statutes for housing condominiums, and by 1967 all but one state had followed suit. ${ }^{8}$ We shall return to Section $\mathrm{V}$ to consider the circumstances surrounding these enactments.

Large-scale formation of condominiums did not immediately follow enactment of the statutes. In fact, relatively few condominium units were created prior to 1970. After that, however, condominiums began to be formed at an accelerating pace-both by new construction and by conversion from rental units-and quickly came to represent a substantial portion of the housing market. Table 2 gives data on the rate of conversion from rental to condominiums and cooperatives in the 1970s, while Table 3 gives data on the rate of new construction. (Although the figures

\footnotetext{
7 Dep't of Housing and Urban Development (HUD), The Conversion of Rental Housing to Condominiums and Cooperatives, app. 1, pt. III, at 17, table IV-2 app. (1980).

${ }^{8}$ Alberto Ferrer \& Karl Stecher, Law of Condominium 129-33 (1967).
} 
TABLE 2

Condominium and Cooperative Conversions, 1970-79

\begin{tabular}{lrrrrr}
\hline \hline & $1970-75$ & 1976 & 1977 & 1978 & \multicolumn{1}{c}{$1979^{*}$} \\
\hline Total units & $\mathbf{8 8 , 7 4 6}$ & 19,976 & 45,445 & 81,504 & 115,143 \\
Condominiums & 85,540 & 19,452 & 43,464 & 75,632 & 108,620 \\
Cooperatives & 3,206 & 524 & 1,981 & 5,872 & 6,523 \\
\hline
\end{tabular}

Source. - U.S. Dep't of Housing and Urban Development, Conversion of Rental Housing to Condominiums and Cooperatives: Volume of Conversion Activity in Selected Metropolitan Areas 4 (1981).

* Represents only first three quarters of 1979.

TABLE 3

New Construction of Condominium and Cooperative Housing Units in Multiunit BulLDINGs, 1973-86 (in Thousands of Units)

\begin{tabular}{lccc}
\hline \hline & $\begin{array}{c}\text { Total } \\
\text { Multifamily }\end{array}$ & $\begin{array}{c}\text { Condo and } \\
\text { Co-op Units }\end{array}$ & $\begin{array}{c}\text { Ratio of Condo } \\
\text { and Co-op Units } \\
\text { to Total Units }\end{array}$ \\
\hline 1973 & 913 & 172 & .19 \\
1974 & 450 & 130 & .29 \\
1975 & 268 & 45 & .17 \\
1976 & 375 & 64 & .17 \\
1977 & 536 & 77 & .14 \\
1978 & 587 & 114 & .19 \\
1979 & 551 & 156 & .28 \\
1980 & 441 & 150 & .34 \\
1981 & 379 & 145 & .38 \\
1982 & 400 & 130 & .32 \\
1983 & 635 & 199 & .31 \\
1984 & 665 & 194 & .29 \\
1985 & 762 & 146 & .19 \\
1986 & 626 & 134 & .21 \\
\hline
\end{tabular}

Source. - U.S. Dep't of Commerce, Statistical Abstract of the United States, 1988, at 683, table 1209 (1987).

in Table 3 combine condominiums and cooperatives, it is likely that the ratio of the two forms approximates that which appears in Table 2-which is to say that the rate of formation of condomiums clearly dominated that of cooperatives.) Moreover, the spread of the condominium form has been nationwide; it now plays an important role in all large metropolitan areas. ${ }^{9}$ As Table 1 shows, cooperatives and condominiums combined accounted for 8.2 percent of all multifamily housing in 1983,

${ }^{9}$ See HUD, supra note 7 , app. 1. 
compared to the market share of roughly 1 percent occupied by cooperatives in 1960.

\section{The Relative Efficiency of Alternative Forms of Ownership}

Tenure choice in multiunit apartment buildings involves a choice between two different means of transacting for the same housing services: rental (a form of market contracting) on the one hand and ownership (a form of vertical integration) through the cooperative or condominium form on the other. Both methods for organizing transactions are costly. The most efficient form is simply the one that is least costly. We shall survey here some of the most important costs of these respective forms.

\section{A. Costs of the Rental Relationship}

The costs of market contracting typically derive from the absence of full information or effective competition. These costs can sometimes be reduced by combining the seller and purchaser under integrated ownership and therefore removing their incentive to exploit market imperfections. Where, as in the case of housing, individuals and households are the purchasers, it is infeasible and illegal for the sellers to own the purchasers; consequently, vertical integration requires that purchasers own sellers. And where many purchasers are served by one seller, as in the case of an apartment building, this requires in turn that the purchasers act collectively through a cooperative.

There are three particular sources of costs in market transactions that commonly provide the incentive for forming consumer cooperatives: market power, lock-in, and moral hazard. ${ }^{10}$ These are also the most likely sources of costs in apartment rentals. We shall consider them here in turn.

\section{Simple Market Power}

Although simple market power, in the sense of fewness of competing sellers, is quite commonly the impetus for consumer ownership of enterprise, ${ }^{11}$ it does not seem plausible as a motivation for the formation of housing cooperatives and condominiums. In urban areas of sufficient density to have multiunit apartment buildings, there are generally large numbers of reasonably fungible apartments under diverse ownership, making the market for apartments quite competitive.

\footnotetext{
10 See Henry Hansmann, Ownership of the Firm, 4 J. L. Econ. \& Org. 267 (1988).

11 Rural electric and telephone utilities, as well as numerous wholesale and supply firms, are commonly organized as consumer cooperatives. See Hansmann, supra note 10.
} 


\section{Market Power Deriving from Exclusivity of the Tenant Population}

There is, however, a more subtle form of market power for landlords that derives, not from the uniqueness of the apartments, but from the uniqueness of the tenants who occupy them.

A landlord who secures a group of tenants who are attractive neighbors can charge more for apartments than he could otherwise. For most classes of tenants, competition among landlords should insure that any such increase in rental is roughly equal to the landlord's costs in selecting tenants. However, in the case of buildings serving social elites such as the prominent rich, a landlord may be in a position to extract pure profits from having a select clientele: such tenants commonly place a substantial premium on having neighbors of high status and may be too few in number to induce a competitive supply of buildings. Moreover, a landlord will often have an incentive to establish a less exclusive clientele than the occupants of the building would choose for themselves. In such circumstances, tenants may be able to improve their welfare considerably by owning the building themselves. ${ }^{12}$

This consideration may help explain why, among the well-to-do, social exclusivity has long been considered an important reason for living in a cooperative apartment building, ${ }^{13}$ and it may have been a significant inducement for the (limited amount of) cooperative housing created prior to the Second World War. ${ }^{14}$ However, it is probably an unimportant factor in most cooperative and, particularly, condominium housing today. The market for such housing now extends well beyond social elites. Moreover, condominiums, in contrast to cooperatives, generally do not screen prospective unit owners on social criteria. ${ }^{15}$

12 See Henry Hansmann, A Theory of Status Organizations, 2 J. L. Econ. \& Org. 119 (1986)

13 J. V. Henderson \& Y. M. Ioannides, A Model of Housing Tenure Choice, 73 Am. Econ. Rev. 98 (1983), offer a countervailing theory, arguing that, ceteris paribus, an increase in an individual's wealth will decrease the likelihood that he will be an owner-occupant. As they note, this result is at odds with observed patterns of tenure choice. One reason, perhaps, is that their conclusion depends entirely on their definition of an "increase in wealth," which involves an increase in exogenous income in each future period that is of equal present value, hence increasing demand for consumption without increasing the need for saving. But increases in wealth taking this form are rare.

14 The ability to choose one's fellow tenants was commonly mentioned in ads and articles concerning cooperatives during this period. See, for example, Cooperative Homes, supra note 2, New York Times, January 3, 1926, sec. 10, at 4, col. 7 ("In many instances the [cooperator's] controlling motive is the desire to escape from undesirable neighborhood conditions and to associate and identify himself with conservative surroundings and with people of his own class").

${ }^{15}$ It seems to be the conventional view that one reason for choosing the cooperative over the condominium form today is that the former provides the occupants of a building with 


\section{Lock-In}

Although the market for apartment rentals may be competitive when an individual is looking for a new apartment, the situation changes after the individual has signed a lease and moved in. The value of the transaction-specific investments that the tenant makes at this time (that is, the costs to the tenant of changing residences again) may be subject to expropriation by the landlord through a rent increase at the time the lease is renewed, when the tenant is to some degree locked in. Conversely, if the tenant decides not to renew the lease, the landlord may incur substantial costs, including the expenses of refurbishing the apartment, advertising it, and forgoing rent while awaiting a new tenant. ${ }^{16}$ Thus both the landlord or the tenant may have a degree of ex post market power after the initial lease has been entered into. Such a bilateral monopoly, and any costly haggling or unpredictability in rent levels that it might engender, can presumably be avoided where tenants own the building they occupy. ${ }^{17}$

The available data indicate that landlords typically charge renewing tenants roughly the same rental ${ }^{18}$ that new tenants are charged for similar

the opportunity to be discriminating when screening new applicants for membership. The usual arrangement in a cooperative is that, subject to the requirements of fair housing legislation, the board of directors may reject any applicant without having to state a reason, thus barring a tenant from assigning his lease until a tenant acceptable to the board is found. In a condominium, in contrast, the board is typically empowered to prevent a sale only by buying the unit itself at the contract price, and condominium boards seldom screen tenants on social criteria. See Michael Hinds, When a Co-op Board Rejects a Buyer, New York Times, November 2, 1986, sec. 8, at 1, col. 2.

However, there are no legal obstacles to giving a condominium board screening powers equivalent to those generally exercised by cooperative boards. That the cooperative form is more commonly used for purposes of personal discrimination perhaps stems from the fact that the members of a cooperative have a strong incentive to screen prospective members to insure that they will carry their share of the collective mortgage on the building-something that condominiums, with their smaller degree of joint financial commitment, have less need for. This financial screening provides a convenient opportunity and cover for engaging in nonfinancial screening as well.

16 The initial lease term also provides the landlord with information as to whether the tenant is a good tenant in the sense that he is nondestructive, prompt in payment, and generally cooperative.

17 Williamson has long emphasized the importance of such transaction-specific investments in explaining vertical integration in other contexts. See Oliver Williamson, The Economic Institutions of Capitalism 61-63 (1985).

18 J. Luis Gausch \& Robert Marshall, A Theoretical and Empirical Analysis of the Length of Residency Discount in the Rental Housing Market, 22 J. Urb. Econ. 291 (1987). Earlier studies, whose methodology is criticized by Gausch and Marshall, had found evidence of discounts for renewing tenants. Allen Goodman \& Masahiro Kawai, Length-of-Residence Discounts and Rental Housing Demand: Theory and Evidence, 61 Land Econ. 93 (1985); William Clark \& Allen Heskin, The Impact of Rent Control on Tenure Discounts and Residential Mobility, 58 Land Econ. 109 (1982). If length-of residence discounts are in fact given, they might be interpreted not as reflecting the direct costs to a landlord of finding a new tenant but rather as an inducement that landlords give to tenants who have revealed themselves during the initial lease term to be good tenants. See Gausch \& Marshall supra. 
units, suggesting that on average the tenant's ex post market power is at least equal to the landlord's. This in turn suggests, though it does not clearly establish, that the transaction costs associated with bilateral monopoly in rentals are too small to provide a significant incentive for occupant ownership.

\section{Moral Hazard}

In a complex long-term transaction such as leasing residential space, the high cost of writing and enforcing contractual provisions that cover all contingencies gives rise to the prospect of moral hazard. Tenants have an incentive to underinvest in maintenance whose benefits will extend beyond the tenant's expected tenure, while landlords have an incentive to underinvest in improvements (such as rapid repairs) whose benefits will be experienced primarily by a current tenant. Occupant ownership can avoid such incentive problems.

The costs resulting from moral hazard may be significant when singlefamily detached houses are rented and presumably help explain the high proportion of owner-occupancy ( 85 percent $)^{19}$ among such dwellings. ${ }^{20}$ It seems likely, however, that these costs are much smaller (in relative terms) in rented apartment units. In the latter, the most important systems requiring long-term investments, such as the exterior shell and the utility systems, are not under the tenant's control and thus not subject to the underinvestment problem. The apartment units themselves generally do not require substantial maintenance by the tenant. Few residential tenants desire substantial physical alterations to the unit they occupy even when such alterations are feasible; those who do can seek to negotiate them separately with the landlord. Security deposits further limit the tenant's incentive to underinvest. In turn, the landlord's incentive to behave opportunistically will be constrained by the advantage of having a good reputation when seeking lease renewals and new rentals.

\section{B. Costs of Occupant Ownership}

If cooperatives and condominiums involved no significant costs that are not experienced in rental relationships, then the costs of market con-

19 U.S. Bureau of the Census, Annual Housing Survey: 1985, ser. H-150, table 2-1.

20 See Henderson \& Ioannides, supra note 13, where it is suggested that, absent problems of risk bearing, this "fundamental rental externality" (as the authors term it) makes ownership more efficient than rental for all households. The authors suggest that risk-bearing considerations are the principal countervailing factor that induces individuals to rent rather than own. They do not deal with the problems of collective ownership, or with the tax subsidies, that are the principal focus here. 
tracting just surveyed, even if relatively modest, would tend to make rental inferior to occupant ownership as a form of tenure. However, occupant ownership also has its unique costs.

\section{Collective Decision Making}

A potentially significant source of costs in residential cooperatives and condominiums, though one that is not often discussed, lies in the collective decision-making mechanisms that these forms require.

a) Inefficient Decisions. If the interests of all members of the cooperative or condominium were identical, the decisions they made collectively would presumably be efficient. ${ }^{21}$ In fact, however, their interests often diverge substantially. For one thing, members vary in their preferences: some will be satisfied with wood-grained vinyl for the elevator walls, while others will strongly prefer spending what is necessary to have real wood; some will want better laundry facilities in the basement, while those who take their laundry out or have their own machines will not. In addition, interests will diverge because the members' apartments differ in structure or location: those on the ground floor may be less eager than those on the top floor to refurbish the elevators. As a consequence, there will be substantial room for outcomes that do not maximize the aggregate surplus of the occupants. This might occur, for example, when the preferences of the median member are different from those of the mean, or when an unrepresentative coalition achieves dominance in collective decisions because their opportunity cost of time is low or because they are otherwise strategically positioned to dominate the decision-making process. ${ }^{22}$

In contrast, the landlord of a rental building, in making decisions that affect the occupants of the building as a group, generally has an incentive to select policies that are efficient since that will maximize the aggregate rents she can charge. ${ }^{23}$ Moreover, the landlord, in contrast to the owneroccupants of a cooperative or condominium, is generally free to choose

${ }^{21}$ If their interests were completely homogeneous, then each unit owner in a cooperative or condominium with $n$ units would pay $1 / n$ of the cost of maintaining the common facilities and receive $1 / n$ of the resulting benefits. Consequently, each unit owner would have an incentive to support a collectively efficient level of maintenance.

22 If exit from a cooperative or condominium were costless, then of course market forces would constrain such costs. But, as noted above in the discussion of lock-in, exit is often costly.

${ }^{23}$ To be sure, this may not be the case if the landlord cannot discriminate freely among his tenants in the rents he charges. In that case, he will have an incentive to choose policies that are attuned to the preferences of the marginal tenant, and this will be inefficient if the marginal tenant's preferences differ from those of the average tenant. See A. Michael Spence, Monopoly, Quality, and Regulation, 6 Bell J. Econ. 417 (1975). 
efficient outcomes since she contracts separately with each individual occupant, thus depriving them of the special opportunity that a voting mechanism gives them to act strategically. In short, market contracting is likely to be more efficient than voting in aggregating the preferences of a building's occupants.

b) Transaction Costs of Decision Making. Quite aside from the efficiency of the decisions ultimately made, there may be substantial transaction costs associated with the process of making collective decisions in a cooperative or condominium, such as the time that the occupants devote to meetings and other governance activities. ${ }^{24} \mathrm{~A}$ single individual acting as landlord can presumably collect information and make decisions with less expenditure of effort. ${ }^{25}$

Moreover, the costs of collective decision making in a cooperative or condominium may be high even in comparison with collective ownership of the same building by a group of nonresident investors acting through a partnership or corporation. To be sure, the members of a cooperative or condominium have some distinct advantages in decision making that nonresident investor-owners lack. The members commonly occupy the building for a number of years and devote a substantial portion of their income to it; consequently, they have both the incentive and the opportunity to invest in information about the building. Moreover, much relevant information about the building is likely to come to the members without extra effort simply because they live there. And, because the members all reside in close proximity to each other, meetings are easy to arrange. In contrast, owners who are merely investors and not occupants will generally be located far from the building and from each other and, consequently, will be in a less advantageous position to exercise effective oversight or make collective decisions. Further, the investors' alternative is to delegate decision-making responsibility to a manager whom they will also have difficulty monitoring and who, lacking full ownership, will have interests that diverge from those of the investors.

On the other hand, investors differ from owner-occupants in having highly homogeneous interests. As a consequence, rental buildings, even when owned collectively by a numerous group of investors, may be spared the high transaction costs of decision making, as well as the poten-

${ }^{24}$ See Richard Lyons, More Co-op Owners Battling Their Boards, New York Times, April 24, 1988 (emphasizing problem of lack of expertise among co-op board members). On the other hand, for some building occupants-particularly retirees-participation in governance may itself be a consumption good and on balance a source of benefits rather than costs.

${ }^{25}$ On the other hand, the process of information gathering and decision making by an individual landlord is not costless. For example, a landlord must still negotiate separately with each tenant, and there may often be room for strategic behavior in those negotiations. 
tially inefficient outcomes, that cooperatives and condominiums incur as a consequence of conflicts in preferences and interests among their members. ${ }^{26}$ And these savings may outweigh the economies that owneroccupants experience in gathering information and communicating with each other. ${ }^{27}$

c) How Costly Is Collective Decision Making? Although it is difficult to obtain direct empirical observations on the costs of collective decisionmaking, ${ }^{28}$ substantial anecdotal and case-law evidence suggests that conflicts among members are, indeed, a serious problem in the governance of cooperatives and condominiums ${ }^{29}$ and that homogeneity of membership is an important aid to viability. ${ }^{30}$ Moreover, the success or failure of cooperative enterprise in a variety of industries other than housing seems strongly correlated with the degree of homogeneity of interest among the members. ${ }^{31}$

${ }^{26}$ One reason for this is that investors in a firm, unlike members of a condominium or a cooperative, have a part interest in the undivided whole, with the result that they are all affected in the same way by any decision taken by the firm. Another reason is that, because the returns to investors are financial rather than in kind, there is little room for divergence of preferences concerning outcomes; the investors in general all have an interest in maximizing the net present value of the firm. To be sure, members may diverge on such issues as retention versus payout of earnings depending on their liquidity and tax status. But even these differences are likely to be minimal since investors can select firms with financial policies that match their particular situation.

27 To see this trade-off more clearly, imagine two identical apartment buildings. Rather than organizing both buildings as cooperatives or condominiums, it might be more efficient to organize them both on a conventional rental basis and have the occupants of one building collectively own the other building through a corporation in which they invest. The nature of the occupants' investments will be similar either way, but the latter arrangement may involve lower costs of governance.

${ }^{28}$ Striking indirect evidence of these costs can be found, however, in the extreme difficulty in organizing multiple owners of drilling rights in a common oil pool to act collectively, even when the potential efficiency gains are very large and the number of owners is relatively small. See Gary D. Libecap \& Steven N. Wiggins, Contractual Responses to the Common Pool, 74 Am. Econ. Rev. 87 (1984).

29 See, for example, Iver Peterson, Budget Battles in Co-ops and Condos, New York Times, January 15, 1989, sec. 10, at 1, col. 4; Ira Robbins, Methods of Holding Residential Property, 190 Annals Am. Acad. Pol. \& Soc. Sci. 109, 111 (1937); Thiess v. Island House Assoc., 311 S.2d 142 (1975); Kaye v. Mount La Jolla Homeowners Assoc., 252 Cal. Rptr. 67 (1988). The much higher rate of owner-occupancy in single-family dwellings rather than in apartments may also reflect in part the relative absence of the costs of collective decision making in the former.

${ }^{30}$ See, for example, testimony of Drayton Bryant, Hearings before the Committee on Banking and Currency, U.S. House of Representatives, 81st Cong., 2d Sess., in H.R. 6618 and H.R. 6742 (superseded by H.R. 7402), January 30-February 14, 1950, at 119: "[V]ery definitely ... the most successful cooperatives have been either in a socially homogeneous group like a union or veteran group or even a church group."

31 See Hansmann, supra note 10, for examples and further discussion. 


\section{Liquidity}

A further liability of owner-occupied housing in general, and of cooperative and condominium housing in particular, is that liquidity constraints may make it costly or impossible for potential owner-occupants to obtain the necessary capital. Although housing provides good security for debt financing, it does not provide perfect security, and there consequently remain substantial agency costs associated with borrowing. ${ }^{32}$ These costs will be reflected in high mortgage interest rates for some owner-occupants or even in the complete unavailability of adequate loans.

On the other hand, we should not draw too strong a distinction between rental and owner-occupancy in this regard. In a sense, a landlord is simply a lender who lends to the tenant the physical unit itself rather than the funds necessary to purchase it. In either case, repossession is the remedy for default on the periodic payments. The principal difference is that the landlord, in contrast to the mortgage lender, specializes in loans for a particular building and combines the act of lending with the provision of other services to the occupants of the units.

\section{Risk Bearing}

Risk bearing is a related problem. Because, for most individuals, the value of the residence they occupy is large relative to their total wealth, home ownership results in poor diversification of their investments relative to rental. In addition, the market value of an individual's residence is likely to be positively correlated with important nonfinancial investments they have made. For example, deterioration in the local job market may well be reflected in a decrease in housing prices; the individual who loses his job may therefore find that the value of his house has decreased at the same time. Or a drop in housing prices may accompany the advent of other problems in the local environment that the occupant must suffer, such as an increase in the crime rate or a decline in the quality of the local schools.

There are, however, contrary cases. In particular, retired persons with fixed nominal incomes from pensions are exposed to serious risk from changes in the inflation rate. By purchasing their residence they can hedge against this risk so far as expenditures on housing are concerned.

32 On the agency costs of debt see, for example, Michael Jensen \& William Meckling, Theory of the Firm: Managerial Behavior, Agency Costs and Ownership Structure, 3 J. Fin. Econ. 305 (1976). 


\section{Transaction Costs of Changing Residences}

The transaction costs associated with moving from one residence to another are commonly lower for renters than for owner-occupants. In particular, the administrative costs of arranging new leases are generally lower than those associated with a change of title and negotiation of new debt financing. ${ }^{33}$ It is presumably for this reason, and perhaps because the costs of collective governance increase with frequent changes in membership, that persons with high expected mobility are more likely than others to choose rental over ownership. ${ }^{34}$

\section{Incentives Facing the Developer}

Finally, when a condominium or cooperative with many units is initially put on the market-whether it is newly constructed or converted from rental-there is a common property problem in assessing the quality of construction. No individual purchaser has an incentive to bear on his own the full cost of inspecting the common features of the building, such as structural elements and utilities, adequately to determine their physical condition. Yet generally the new purchasers have no way to act in concert to share the costs of such an inspection. Consequently, the developer of the building has an incentive to provide inefficiently low quality. We might therefore expect condominiums to exhibit the characteristics of a "lemons" market, ${ }^{35}$ and there is some evidence that this has happened ${ }^{36}$ In contrast, a single purchaser who will operate the building on a rental basis as a landlord, like the purchaser of a single-family house, receives the full benefit of an inspection and, therefore, has an appropriate incentive to undertake it.

\section{The Relative Efficiency of Rental and Ownership}

From the preceding survey of the types of costs unique to each form, it is not obvious a priori whether rental or owner-occupany is most efficient for an apartment building in any particular context. If there were no other considerations involved, then a simple survivorship test would

${ }^{33}$ As discussed in note 94 infra, however, it is not obvious that there need be a large cost disparity in this regard.

34 See Michael Lea \& Michael Wasylenko, Tenure Choice and Condominium Conversion, 14 J. Urb. Econ. 127 (1983).

35 George Akerlof, The Market for "Lemons": Quality Uncertainty and the Market Mechanism, 84 Q. J. Econ. 488 (1970).

${ }^{36}$ Consumer distrust of condominium developers was both reflected and fueled by John D. MacDonald, Condominium (1977), a popular muckraking novel that hangs its entire plot on the lemons problem in early Florida condominium construction. 
presumably provide the answer: in the long run, market forces would lead condominiums and cooperatives to displace rental buildings where and only where the aggregate costs associated with the former are lower. Moreover, changes over time in the market share of cooperatives and condominiums would presumably reflect changes in these costs.

But the choice between rental and owner-occupany is also strongly affected by taxation. Consequently, a survivorship test is misleading without first taking into account the disparate tax treatment afforded the two forms of tenancy.

\section{TAx Subsidies}

The federal personal income tax, as presently structured, contains large subsidies for both rental and owner-occupied housing. The relative magnitude of these subsidies determines the net tax subsidy to owner-occupied as opposed to rental housing-that is, the bias in favor of owneroccupancy that is created by the current tax system, as compared to a world with no taxes or a world with a tax system that is neutral between the two forms of ownership. Surprisingly, the existing public finance literature contains no accurate estimate of this net subsidy. Such an estimate will consequently be presented here, together with an estimate of the changes in the magnitude of the net subsidy over the past fifty years.

\section{A. Tax Subsidies to Owner-Occupants}

\section{The Structure of the Subsidy}

Although, in the popular mind, the tax subsidy to homeownership visà-vis rental is often associated with the ability to deduct mortgage interest and property taxes when computing taxable personal income,${ }^{37}$ these deductions are in fact not a source of subsidy. ${ }^{38}$ Landlords can also take these deductions, and in competitive markets-which rental markets presumably are-the value of the deductions will be passed through to tenants. Rather, as sophisticated analysts have long recognized, the principal source of the subsidy lies in the failure to include the imputed rental value

37 Internal Revenue Code (I.R.C.) $\$ \S 163,164$ (1986). These deductions were well established by 1936, the earliest year covered by the data below. I.R.C. $\$ 23$ (1936).

38 The confusion is widespread. For example, the leading legal treatise on condominiums states that the deductibility of mortgage interest and property taxes is the source of the tax benefits for condominium housing vis-à-vis rental and is an important reason to choose the condominium form. Patrick Rohan \& Melvin Reskin, Condominium Law and Practice 1 (the introduction) (1988). 
of owner-occupied housing in taxable personal income. ${ }^{39}$ The value of this tax subsidy is offset somewhat by the fact that owner-occupants, in contrast to landlords, are not permitted a deduction for depreciation..$^{40}$ The absence of the latter deduction, however, is generally far from sufficient to offset the value of the exclusion of imputed rental income, as the computations reported below reveal.

In addition, since 1951 owner-occupied housing has benefited from a special rule that defers taxation of capital gains on sale of a residence so long as the proceeds of the sale are reinvested in another owner-occupied

39 To see clearly the nature of the subsidy, imagine a situation in which two identical taxpayers occupy identical houses. Then consider two different ways in which these individuals might structure ownership of their houses: in the first, each occupant simply owns his own house; in the second, each individual owns the house occupied by the other and rents the house to the other for a fair market rental (which is identical for the two houses). In the absence of taxes, and setting aside transaction cost and incentive issues of the type discussed in Section III above, the two different ownership structures are financially equivalent, and the individuals should be indifferent between them. Their invested capital and annual net income flows are the same in each. Under the tax laws, however, the second approach is far less attractive since the amount each individual receives as rent on the house he owns is taxable income, while the (equivalent) amount he pays as rent on the house he occupies is not deductible. The reason for the distinction is that in general the tax code only taxes transactions between two distinct persons. When an individual is his own landlord, there is no such transaction.

There are several ways to eliminate the disparity in the taxation of rented and owneroccupied housing. One is to tax the imputed rental income of owner-occupants. Another is to permit tenants a deduction for rental payments. A third is to permit landlords to exclude from income the rental payments they receive from tenants. If everyone were in the same marginal tax bracket, and if the expense deductions permitted landlords and owner-occupants were also equalized (for example, by extending depreciation deductions to owneroccupants as well as landlords), then these three approaches would all be equivalent, except that the second and third would maintain a subsidy for housing in general (whether rented or owner-occupied) as opposed to investments in other income-producing assets, while the first would create a less favorable tax regime for housing than for other consumer durables such as automobiles and appliances, which are also subject to a tax bias in favor of ownership rather than leasing.

Several European countries either now tax, or have in the recent past taxed, imputed rental income from housing-including England, France, Germany, Italy, Sweden, and Switzerland-though there is reason to doubt the efficacy of these efforts. See Richard Goode, The Individual Income Tax 121 (1964) (England); and Harvard Internat'l Tax Program, World Tax Series: Taxation in France 532-37 (1966), as well as comparable volumes in this series for the other countries mentioned.

${ }^{40}$ It is also the case that owner-occupants, in contrast to landlords, are not permitted to take deductions for current expenses such as maintenance and utilities. Unlike the denial of depreciation deductions, however, this does not create a bias in favor of rental. The reason is that an owner is also permitted to exclude from income the imputed amount he would have to pay himself as landlord to cover these costs, and this exclusion just balances the absence of the deduction. Or, viewing it the other way, the landlord must include as income the amounts charged tenants for maintenance and utilities, and then gets a deduction in equivalent amount for these expenses, thus making the net tax effect zero, just as it is for an owner. 
residence. ${ }^{41}$ This rule was supplemented in 1963 by another provision granting a onetime forgiveness of accumulated capital gains from the sale of a personal residence when a taxpayer is over 55 years of age. ${ }^{42}$

\section{Application to Cooperatives and Condominiums}

Since 1942, tenant-stockholders in housing cooperatives have been permitted to deduct their proportionate share of the mortgage interest and property taxes paid by the cooperative. ${ }^{43}$ Prior to that time, no such deduction was permitted. ${ }^{44}$ This does not mean that cooperatives could not take advantage of the full tax subsidy to owner-occupied housing prior to 1942; rather, it means that, to get the full subsidy before that year, the building could not be financed with a mortgage but instead had to be owned outright by its members ${ }^{45}$ - which is probably the way that the luxury buildings that then accounted for most cooperatives were generally financed.

There is no special provision in the Internal Revenue Code that permits owner-occupants of condominium units to take deductions for property taxes and mortgage interest; rather, the deductions are allowed under the same provisions that apply to homeowners in general. Allowance for these deductions was first explicitly recognized by the Internal Revenue Service in $1964 .^{46}$ It is not clear whether owners of condominium units prior to that time generally understood that these deductions were available, although some commentators have argued that the deductions were always implicit in the general provisions of the code. ${ }^{47}$

41 I.R.C. $\$ 1034$ (1986); I.R.C. § 112 (n) (1952).

42 This exclusion has, however, always been subject to a (reasonably generous) ceiling, which has been increased at intervals through the years; at present the ceiling is $\$ 125,000$. I.R.C. $\$ 121$ (1986).

${ }^{43}$ I.R.C. $\$ 216$ (1986), originally enacted as $\$ 128$ of the Revenue Act of 1942 . A cooperative housing corporation, like a condominium association, is not itself exempt from taxes. Commissioner v. Lake Forest, Inc., 305 F.2d 814 (4th Cir. 1962). They rarely pay taxes, however, since they generally assess their members for an amount no greater than their expenses and thus have no taxable income. See 2 Patrick Rohan \& Melvin Reskin, Cooperative Housing: Law and Practice sec. 15.01 (1986).

44 See id., sec. 13.01.

${ }^{45}$ This is most easily seen by comparing $(a)$ the situation in which a homeowner purchases a $\$ 100,000$ home outright, with no mortgage, with $(b)$ that in which the same home is purchased entirely with borrowed money, while the owner's $\$ 100,000$ is instead invested and the returns from that investment used to help pay the interest on the mortgage. If the homeowner's interest rates for borrowing and lending were the same, then for tax purposes the two transactions would be identical if mortgage interest were a deductible expense. But if mortgage interest were not deductible, then only transaction $a$ would have the advantage of the tax subsidy described in note 39 supra.

${ }^{46}$ Rev. Rul. 64-31, 1964-1 C.B. 300, 302.

${ }^{47}$ See David Clurman \& Edna Hebard, Condominiums and Cooperatives 140 (1970). 
TABLE 4

Marginal Tax Rates

\begin{tabular}{lcccccccc}
\hline \hline & \multicolumn{7}{c}{ Household's Position IN InCOME Distribution } \\
\cline { 2 - 9 } & $20 \%$ & $40 \%$ & $50 \%$ & $60 \%$ & $80 \%$ & $95 \%$ & $99 \%$ & Top \\
\hline 1936 & 0 & 0 & 0 & 0 & 0 & 0 & 6 & 79 \\
1946 & 17 & 17 & 19 & 19 & 19 & 27 & 35 & 86 \\
1956 & 20 & 21 & 24 & 24 & 26 & 32 & 43 & 91 \\
1966 & 18 & 20 & 22 & 22 & 27 & 36 & 46 & 70 \\
1976 & 19 & 25 & 27 & 28 & 36 & 45 & 58 & 70 \\
1985 & 17 & 24 & 28 & 32 & 42 & 45 & 48 & 50 \\
1988 & 15 & 15 & 15 & 28 & 28 & 28 & 28 & 28 \\
\hline
\end{tabular}

Sources. - Computed by applying tax tables for respective years to income figures in Table 5. Figures for 1988 were computed by applying 1988 tax rates to 1985 income figures.

\section{Interaction with Tax Brackets}

The value of these subsidies is roughly proportional to the owner's marginal tax rate (or, more precisely, the average tax rate that would be applicable to the owner's imputed rental income if it were taxed). An individual in a high tax bracket receives a substantial subsidy, while an individual who pays no taxes receives no subsidy at all.

Because tax rates have changed over time, the value of the tax subsidy to owner-occupancy has changed, too. In general, average tax rates have increased through the years and jumped especially sharply at the time of the Second World War. To provide some sense of this, Table 4 gives an estimate, for a series of years between 1936 and 1988, of the marginal tax bracket facing persons at different points in the income distribution. The first column, for example, gives the marginal tax bracket of a person whose income falls at the twentieth percentile (from the bottom) of the income distribution, while the seventh column gives the marginal tax bracket confronting a person in the ninety-ninth percentile (that is, the top 1 percent of the income distribution). ${ }^{48}$ The eighth column gives the highest marginal rate applied to anyone in the year in question. The latter rate, it should be noted, applies to very few individuals for the years 1936-56. In 1936, for example, the top rate applied to incomes in excess of $\$ 5$ million, while median household income in that year was only $\$ 1,069$, and an income of $\$ 9,258$ put a household in the top 1 percent of the distribution (see Table 5).

48 In fact, Table 4 almost surely gives an overestimate of effective marginal tax rates because it uses rates applicable to the household income figures from Table 5, and the latter figures are probably higher in general than the adjusted gross income figures to which the marginal tax rates actually apply. 
TABLE 5

Household Income Distribution in CurRent Dollars

\begin{tabular}{lrrrrrrr}
\hline \multicolumn{7}{c}{ HousEHOLD's POSITION IN INCOME DISTRIBUTION } \\
\cline { 2 - 8 } & $20 \%$ & $40 \%$ & $50 \%$ & $60 \%$ & $80 \%$ & $95 \%$ & $99 \%$ \\
\hline 1936 & 551 & 890 & 1,069 & 1,272 & 1,922 & 3,453 & 9,258 \\
1946 & 1,024 & 1,988 & 2,417 & 2,867 & 4,105 & 7,721 & 10,791 \\
1956 & 1,648 & 3,451 & 4,226 & 4,984 & 6,952 & 11,633 & 18,871 \\
1966 & 2,556 & 5,263 & 6,465 & 7,691 & 11,000 & 19,355 & 28,869 \\
1976 & 5,462 & 10,197 & 12,686 & 15,399 & 22,142 & 35,174 & 56,649 \\
1985 & 9,999 & 18,945 & 23,618 & 29,529 & 45,158 & 67,018 & 105,466 \\
\hline
\end{tabular}

SourCES.-Computed by interpolation (or, in the case of the ninety-ninth percentile, extrapolation) from U.S. Dep't of Commerce, Bureau of the Census, Current Population Reports, Consumer Income Ser. P-60, no. 1 Rev., at 17 , table 3 ; no. 27 , at 23 , table 5; no. 53, at 23 , table 1; U.S. Bureau of the Census, Statistical Abstract of the United States: 1938, at 304, table 346.

Table 4 shows that the tax subsidy to owner-occupied housing was nonexistent for everyone except those in roughly the top 1 percent of the income distribution in 1936, and, even for many households in the top 1 percent, the tax rate was so low as to make the subsidy quite modest. After the war, however, tax rates became large enough to make the subsidy significant for the great majority of households, and increasingly so through the middle 1970 s.

We cannot, however, conclude from Table 4 alone that the tax code in recent decades has provided a substantial incentive for owner-occupancy as opposed to rental since the tax code also subsidizes rental housing.

\section{B. Tax Subsidies to Landlords}

The federal tax code provides a subsidy to rental properties vis-à-vis other investments to the extent that it permits the owner of a rental building to take depreciation deductions that exceed the real rate of economic depreciation. In particular, between 1954 and 1986 the tax code made depreciation deductions extremely generous by permitting them to be computed according to the double declining balance method. ${ }^{49}$ Moreover, landlords were allowed to finance rental buildings through limited partnerships that permitted outside investors (serving as the limited partners) to shelter income they received from other sources by offsetting against it the large tax losses that the depreciation rules generated in

49 I.R.C. $\$ 167$ (1986). For the years before and after this, straight-line depreciation was the method generally called for. I.R.C. $\$ 23(1)$ (1936), (1946); I.R.C. $\S 167$ (1988). An appendix with details of computation is available from me on request. 
the early years of the real estate investment. The result was that the depreciation deductions could effectively be sold to taxpayers in high tax brackets, thus permitting landlords to extract maximum value from the deductions.

The value of the excess depreciation deductions has, however, been limited in some years by two devices. The first is a "recapture" rule under which, at the time a building is sold, taxes must be paid at ordinary income rates on some or all of that portion of the capital gain accounted for by accelerated depreciation deductions. ${ }^{50}$ The recapture rules first came into effect in 1963 and were subsequently stiffened in 1970 and 1976.51

The second device is a "minimum" tax rate applied to certain tax preference items if they exceed a given total. Accelerated depreciation and capital gains are among the tax preference items affected. The minimum tax first took effect in 1970, with a rate of 10 percent. In 1976 the rate was increased to 15 percent, and the tax was otherwise tightened then as well. Since 1983 the rate for the minimum tax has been 20 percent.

The Tax Reform Act of 1986 severely diminished the tax subsidy to rental housing. Depreciation deductions were substantially reduced and in many cases limited to the straight-line method. The minimum "useful life" over which a building could be depreciated was increased to 27.5 years. (It had been as low as 15 years from 1981 to 1984.) The capital gains exclusion was eliminated, leaving capital gains from the sale of a building to be taxed at the same rate as ordinary income. The maximum marginal tax rate was reduced from 50 percent to 33 percent, and to 28 percent for the wealthiest taxpayers, thus reducing the value of depreciation deductions. Taxpayers were prohibited from offsetting ordinary earned income with "passive" losses from investments in real estate. ${ }^{52}$ And, finally, an "at-risk rule" was adopted to prevent investors from using nonrecourse debt as leverage to increase the value of depreciation deductions per dollar invested. ${ }^{53}$ The effect was essentially to eliminate the familiar real estate tax shelter. Although the minimum tax was retained, the changes just described render it largely irrelevant so far as ownership of rental property is concerned.

\footnotetext{
so That is, on the amount by which the accumulated depreciation deductions taken exceed those that could have been taken under a straight-line depreciation method. Details of computation are in my appendix.

5t For a more detailed account in the context of computations similar to those undertaken here, see Patric Hendershott \& James Shilling, The Economics of Tenure Choice, 1955-79, in Research in Real Estate 105, 114-15 (C. F. Sirmans ed. 1982).

52 I.R.C. \$ 469.-

53 I.R.C. $\$ 465$.
} 


\section{The Value of the Net Subsidy to Owner-Occupancy}

The value of the net tax subsidy to owner-occupied as opposed to rental housing is the difference in value between the respective tax subsidies to owner-occupied and rental properties just described. The magnitude of these two sets of subsidies, and thus of their difference, depends on a variety of factors that vary over time and across individuals. These factors include the respective tax brackets of the occupants and owners of buildings, prevailing interest and inflation rates, and the specific tax rules in effect.

Several recent studies have undertaken computations of the differential tax subsidy to owner-occupied versus rental housing for various spans of time and have sought to determine the influence of this net subsidy on tenure choice (that is, on the choice between owner-occupancy and rental). ${ }^{54}$ These studies are not directly suited to the purpose at hand here, however, for several reasons. First, they all conflate the tenure choice issue with the choice of type of housing. That is, they assume explicity or implicitly that the choice involved is between renting a unit in an apartment building or purchasing a single-family home, rather than simply between occupying a given unit in an apartment building either as a renter or as an owner. Thus, in these studies, tax considerations are inextricably intertwined with other factors that make the own/rent tenure choice different for these two different types of housing. Second, the preceding problem is compounded in most of these studies by the fact that the figure they use for the after-tax cost of rental is simply an empirically observed market rental rate that reflects a variety of nontax considerations. Third, none of these studies extend back in time to the period before the Second World War, and thus they do not permit a comparison of recent years with the markedly different tax regime that prevailed then.

Only one sophisticated study, by Patric Hendershott and James Shilling, ${ }^{55}$ avoids the second of the preceding problems by computing the cost of both renting and owning as the present value of the expected stream of after-tax cash flows that an individual would expect to face under the type of tenure in question. Using this method, Hendershott and Shilling derive an estimate of the relative costs of owning and renting

\footnotetext{
54 Hendershott \& Shilling, supra note 51; Harvey Rosen, Housing Decisions and the U.S. Income Tax: An Econometric Analysis, 11 J. Pub. Econ. 1 (1979); Harvey Rosen \& Kenneth Rosen, Federal Taxes and Homeownership: Evidence from Time Series, $88 \mathrm{~J}$. Pol. Econ. 59 (1980). An earlier and less sophisticated effort appears in John Shelton. The Cost of Renting versus Owning a Home, 44 Land Econ. 59 (1968). See also Harvey Rosen, Housing Subsidies: Effects on Housing Decisions, Efficiency, and Equity, in 1 Handbook of Public Economics 375 (Alan J. Auerbach \& Martin S. Feldstein eds. 1985).

${ }^{55}$ Hendershott \& Shilling, supra note 51.
} 
for each quarter between 1955 and 1979. Unfortunately, even these results cannot be used directly to compare the relative advantage of organizing a given building as a rental building versus a cooperative or condominium. The most important reason for this is that Hendershott and Shilling's computations are infected with the first problem described above: they impute some costs to the rental form that they do not to owner-occupancy, and vice versa, on the assumption that different types of structures are involved. In addition, their results are influenced, in some cases strongly, by particular assumptions about which reasonable analysts might differ-for example, concerning expected inflation in housing prices. ${ }^{56}$

Consequently, new calculations have been undertaken here to develop a more accurate measure of the net tax subsidy to cooperatives and condominiums as opposed to rental housing. The method used is similar to that employed by Hendershott and Shilling. The cost of housing for owner-occupants in a given year was computed as the present value of the future after-tax cash flows that an individual would reasonably have expected if he were to buy his living unit in that year. These costs were computed over the period of years that an average individual would be likely to own a home. (Because of the nature of the tax rules applicable to owner-occupied housing, the calculation is in most cases invariant to the number of years assumed.)

Similarly, the cost to a landlord of renting out a unit in a given year was computed as the present value of the future after-tax cash expenses that the landlord would reasonably have expected if she purchased a building in that year, computed over the number of years that she would reasonably plan to own the building if she were to seek to minimize her after-tax costs. This becomes the cost for renters if the landlord charges a rental just equal to the landlord's full cost (which here includes a market rate of return on capital and services); the conditions under which this will occur are discussed below.

In effect, these calculations give the annual cost of owner-occupancy and of rental, respectively, per dollar spent on the initial purchase price of the building. In the long run, the purchase price of a building should be determined by the cost of construction and should, therefore, be the same whether the purchaser is a landlord or a condominium association. Consequently, by comparing the figures yielded by these calculations we obtain a measure of the difference in cost that results, by virtue of the

\footnotetext{
56 An appendix (available from me on request) shows the sensitivity of the computations to differing assumptions concerning the most important variables.
} 
TABLE 6

After-Tax Cost of Housing as a \% of Building Value

\begin{tabular}{|c|c|c|c|c|c|c|c|c|}
\hline & \multicolumn{8}{|c|}{ Landlord/OWner-OCCuPant's Position in Income Distribution } \\
\hline & $20 \%$ & $40 \%$ & $50 \%$ & $60 \%$ & $80 \%$ & $95 \%$ & $99 \%$ & Top \\
\hline \multicolumn{9}{|c|}{ A. No minimum tax: } \\
\hline \multicolumn{9}{|c|}{ 1936: } \\
\hline Rent & 5.08 & 5.08 & 5.08 & 5.08 & 5.08 & 5.08 & 5.03 & 6.70 \\
\hline Own & 5.08 & 5.08 & 5.08 & 5.08 & 5.08 & 5.08 & 4.77 & 1.63 \\
\hline \multicolumn{9}{|l|}{ 1946: } \\
\hline Rent & 4.21 & 4.21 & 4.13 & 4.13 & 4.13 & 3.78 & 3.35 & 7.45 \\
\hline Own & 3.73 & 3.73 & 3.61 & 3.61 & 3.61 & 3.12 & 2.64 & -.11 \\
\hline \multicolumn{9}{|l|}{ 1956: } \\
\hline Rent & 7.13 & 7.09 & 6.99 & 6.99 & 6.91 & 6.67 & 6.10 & -3.92 \\
\hline Own & 6.16 & 6.08 & 5.85 & 5.85 & 5.70 & 5.23 & 4.39 & 1.43 \\
\hline \multicolumn{9}{|l|}{ 1966: } \\
\hline Rent & 6.76 & 6.68 & 6.60 & 6.60 & 6.38 & 5.92 & 5.50 & 3.85 \\
\hline Own & 5.89 & 5.73 & 5.57 & 5.57 & 5.17 & 4.44 & 3.78 & 2.32 \\
\hline \multicolumn{9}{|l|}{ 1976: } \\
\hline Rent & 3.22 & 2.69 & 2.50 & 2.41 & 2.02 & 1.45 & .18 & -1.95 \\
\hline Own & 2.51 & 1.86 & 1.65 & 1.54 & .98 & .34 & -.58 & -1.43 \\
\hline \multicolumn{9}{|l|}{ 1985: } \\
\hline Rent & 8.08 & 7.62 & 7.44 & 7.23 & 6.61 & 6.38 & 6.12 & 5.93 \\
\hline Own & 7.12 & 6.19 & 5.65 & 5.12 & 3.79 & 3.43 & 3.16 & 2.97 \\
\hline \multicolumn{9}{|l|}{ 1988: } \\
\hline Rent & 8.88 & 8.88 & 8.88 & 8.83 & 8.83 & 8.83 & 8.83 & 8.83 \\
\hline Own & 7.39 & 7.39 & 7.39 & 5.65 & 5.65 & 5.65 & 5.65 & 5.65 \\
\hline \multicolumn{9}{|c|}{$\begin{array}{l}\text { B. Minimum tax ap- } \\
\text { plied to landlord: } \\
\text { 1976: }\end{array}$} \\
\hline Rent & 3.87 & 3.41 & 3.25 & 3.17 & 2.87 & 2.44 & 1.48 & -.14 \\
\hline \multicolumn{9}{|l|}{ 1985: } \\
\hline Rent & 8.74 & 8.34 & 8.20 & 8.05 & 7.56 & 7.38 & 7.18 & 7.03 \\
\hline
\end{tabular}

tax code alone, from operating the same building on a rental basis on the one hand or as a cooperative or condominium on the other.

These computations were undertaken for the years 1936, 1946, 1956, 1966, 1976, and 1985. In addition, figures were projected for 1988 by recomputing the results for 1985 using the tax rules in effect in 1988. The results are given in Tables 6 and $7 . .^{57}$

Table 6 gives the annual cost of housing for both rental and owneroccupancy for each of the years in question, stated as a percentage of the market value of the building. Or, more precisely, the figures in Table

57 The equations and data used for these computations are described in detail in my appendix. 
TABLE 7

Difference between Rental Cost and Owner-Occupancy Cost as a \% of Building Value

\begin{tabular}{|c|c|c|c|c|c|c|c|c|}
\hline \multirow{2}{*}{$\begin{array}{l}\text { OWNER'S POSITION IN } \\
\text { INCOME DISTRIBUTION }\end{array}$} & \multicolumn{8}{|c|}{ Marginal LandLord's Position in InCOME Distribution } \\
\hline & $20 \%$ & $40 \%$ & $50 \%$ & $60 \%$ & $80 \%$ & $95 \%$ & $99 \%$ & Top \\
\hline \multicolumn{9}{|c|}{$\begin{array}{l}\text { A. No minimum tax is } \\
\text { applied to marginal } \\
\text { landlord: }\end{array}$} \\
\hline \multicolumn{9}{|c|}{ 1936: } \\
\hline 20 & .00 & .00 & .00 & .00 & .00 & .00 & -.05 & 1.62 \\
\hline 40 & .00 & .00 & .00 & .00 & .00 & .00 & -.05 & 1.62 \\
\hline 50 & .00 & .00 & .00 & .00 & .00 & .00 & -.05 & 1.62 \\
\hline 60 & .00 & .00 & .00 & .00 & .00 & .00 & -.05 & 1.62 \\
\hline 80 & .00 & .00 & .00 & .00 & .00 & .00 & -.05 & 1.62 \\
\hline 95 & .00 & .00 & .00 & .00 & .00 & .00 & -.05 & 1.62 \\
\hline 99 & .31 & .31 & .31 & .31 & .31 & .31 & .26 & 1.93 \\
\hline Top & 3.45 & 3.45 & 3.45 & 3.45 & 3.45 & 3.45 & 3.40 & 5.07 \\
\hline \multicolumn{9}{|l|}{ 1946: } \\
\hline 20 & .48 & .48 & .40 & .40 & .40 & .05 & -.38 & -11.18 \\
\hline 40 & .48 & .48 & .40 & .40 & .40 & .05 & -.38 & -11.18 \\
\hline 50 & .60 & .60 & .52 & .52 & .52 & .17 & -.26 & -11.06 \\
\hline 60 & .60 & .60 & .52 & .52 & .52 & .17 & -.26 & -11.06 \\
\hline 80 & .60 & .60 & .52 & .52 & .52 & .17 & -.26 & -11.06 \\
\hline 95 & 1.09 & 1.09 & 1.01 & 1.01 & 1.01 & .66 & .23 & -10.57 \\
\hline 99 & 1.57 & 1.57 & 1.49 & 1.49 & 1.49 & 1.14 & .71 & -10.09 \\
\hline Top & 4.32 & 4.32 & 4.24 & 4.24 & 4.24 & 3.89 & 3.46 & -7.34 \\
\hline \multicolumn{9}{|l|}{ 1956: } \\
\hline 20 & .97 & .93 & .83 & .83 & .75 & .51 & -.06 & -10.08 \\
\hline 40 & 1.05 & 1.01 & .91 & .91 & .83 & .59 & .02 & -10.00 \\
\hline 50 & 1.28 & 1.24 & 1.14 & 1.14 & 1.06 & .82 & .25 & -9.77 \\
\hline 60 & 1.28 & 1.24 & 1.14 & 1.14 & 1.06 & .82 & .25 & -9.77 \\
\hline 80 & 1.43 & 1.39 & 1.29 & 1.29 & 1.21 & .97 & .40 & -9.62 \\
\hline 95 & 1.90 & 1.86 & 1.76 & 1.76 & 1.68 & 1.44 & .87 & -9.15 \\
\hline 99 & 2.74 & 2.70 & 2.60 & 2.60 & 2.52 & 2.28 & 1.71 & -8.31 \\
\hline Top & 5.70 & 5.66 & 5.56 & 5.56 & 5.48 & 5.24 & 4.67 & -5.35 \\
\hline \multicolumn{9}{|l|}{ 1966: } \\
\hline 20 & .87 & .79 & .71 & .71 & .49 & .03 & -.39 & -2.04 \\
\hline 40 & 1.03 & .95 & .87 & .87 & .65 & .19 & -.23 & -1.88 \\
\hline 50 & 1.19 & 1.11 & 1.03 & 1.03 & .81 & .35 & -.07 & -1.72 \\
\hline 60 & 1.19 & 1.11 & 1.03 & 1.03 & .81 & .35 & -.07 & -1.72 \\
\hline 80 & 1.59 & 1.51 & 1.43 & 1.43 & 1.21 & .75 & .33 & -1.32 \\
\hline 95 & 2.32 & 2.24 & 2.16 & 2.16 & 1.94 & 1.48 & 1.06 & -.59 \\
\hline 99 & 2.98 & 2.90 & 2.82 & 2.82 & 2.60 & 2.14 & 1.72 & .07 \\
\hline Top & 4.44 & 4.36 & 4.28 & 4.28 & 4.06 & 3.60 & 3.18 & 1.53 \\
\hline \multicolumn{9}{|l|}{ 1976: } \\
\hline 20 & .71 & .18 & -.01 & -.10 & -.49 & -1.06 & -2.33 & -4.46 \\
\hline 40 & 1.36 & .83 & .64 & .55 & .16 & -.41 & -1.68 & -3.81 \\
\hline 50 & 1.57 & 1.04 & .85 & .76 & .37 & -.20 & -1.47 & -3.60 \\
\hline 60 & 1.68 & 1.15 & .96 & .87 & .48 & -.09 & -1.36 & -3.49 \\
\hline 80 & 2.24 & 1.71 & 1.52 & 1.43 & 1.04 & .47 & -.80 & -2.93 \\
\hline 95 & 2.88 & 2.35 & 2.16 & 2.07 & 1.68 & 1.11 & -.16 & -2.29 \\
\hline 99 & 3.80 & 3.27 & 3.08 & 2.99 & 2.60 & 2.03 & .76 & -1.37 \\
\hline Top & 4.65 & 4.12 & 3.93 & 3.84 & 3.45 & 2.88 & 1.61 & -.52 \\
\hline
\end{tabular}


TABLE 7 (Continued)

\begin{tabular}{|c|c|c|c|c|c|c|c|c|}
\hline \multirow{2}{*}{$\begin{array}{l}\text { OWNER'S POSITION IN } \\
\text { InCOME Distribution }\end{array}$} & \multicolumn{8}{|c|}{ Marginal. Landlord's Position in Income Distribution } \\
\hline & $20 \%$ & $40 \%$ & $50 \%$ & $60 \%$ & $80 \%$ & $95 \%$ & $99 \%$ & Top \\
\hline \multicolumn{9}{|l|}{ 1985: } \\
\hline 20 & .96 & .50 & .32 & .11 & -.51 & -.74 & -1.00 & -1.19 \\
\hline 40 & 1.89 & 1.43 & 1.25 & 1.04 & .42 & .19 & -.07 & -.26 \\
\hline 50 & 2.43 & 1.97 & 1.79 & 1.58 & .96 & .73 & .47 & .28 \\
\hline 60 & 2.96 & 2.50 & 2.32 & 2.11 & 1.49 & 1.26 & 1.00 & .81 \\
\hline 80 & 4.29 & 3.83 & 3.65 & 3.44 & 2.82 & 2.59 & 2.33 & 2.14 \\
\hline 95 & 4.65 & 4.19 & 4.01 & 3.80 & 3.18 & 2.95 & 2.69 & 2.50 \\
\hline 99 & 4.92 & 4.46 & 4.28 & 4.07 & 3.45 & 3.22 & 2.96 & 2.77 \\
\hline Top & 5.11 & 4.65 & 4.47 & 4.26 & 3.64 & 3.41 & 3.15 & 2.96 \\
\hline \multicolumn{9}{|l|}{ 1988: } \\
\hline 20 & 1.49 & 1.49 & 1.49 & 1.44 & 1.44 & 1.44 & 1.44 & 1.44 \\
\hline 40 & 1.49 & 1.49 & 1.49 & 1.44 & 1.44 & 1.44 & 1.44 & 1.44 \\
\hline 50 & 1.49 & 1.49 & 1.49 & 1.44 & 1.44 & 1.44 & 1.44 & 1.44 \\
\hline 60 & 3.23 & 3.23 & 3.23 & 3.18 & 3.18 & 3.18 & 3.18 & 3.18 \\
\hline 80 & 3.23 & 3.23 & 3.23 & 3.18 & 3.18 & 3.18 & 3.18 & 3.18 \\
\hline 95 & 3.23 & 3.23 & 3.23 & 3.18 & 3.18 & 3.18 & 3.18 & 3.18 \\
\hline 99 & 3.23 & 3.23 & 3.23 & 3.18 & 3.18 & 3.18 & 3.18 & 3.18 \\
\hline Top & 3.23 & 3.23 & 3.23 & 3.18 & 3.18 & 3.18 & 3.18 & 3.18 \\
\hline \multicolumn{9}{|c|}{$\begin{array}{l}\text { B. Minimum tax is applied } \\
\text { to marginal } \\
\text { landlord: }\end{array}$} \\
\hline \multicolumn{9}{|c|}{ 1976: } \\
\hline 20 & 1.36 & .90 & .74 & .66 & .36 & -.07 & -1.03 & -2.65 \\
\hline 40 & 2.01 & 1.55 & 1.39 & 1.31 & 1.01 & .58 & -.38 & -2.00 \\
\hline 50 & 2.22 & 1.76 & 1.60 & 1.52 & 1.22 & .79 & -.17 & -1.79 \\
\hline 60 & 2.33 & 1.87 & 1.71 & 1.63 & 1.33 & .90 & -.06 & -1.68 \\
\hline 80 & 2.89 & 2.43 & 2.27 & 2.19 & 1.89 & 1.46 & .50 & -1.12 \\
\hline 95 & 3.53 & 3.07 & 2.91 & 2.83 & 2.53 & 2.10 & 1.14 & -.48 \\
\hline 99 & 4.45 & 3.99 & 3.83 & 3.75 & 3.45 & 3.02 & 2.06 & .44 \\
\hline Top & 5.30 & 4.84 & 4.68 & 4.60 & 4.30 & 3.87 & 2.91 & 1.29 \\
\hline \multicolumn{9}{|l|}{ 1985: } \\
\hline 20 & 1.62 & 1.22 & 1.08 & .93 & .44 & .26 & .06 & -.09 \\
\hline 40 & 2.55 & 2.15 & 2.01 & 1.86 & 1.37 & 1.19 & .99 & .84 \\
\hline 50 & 3.09 & 2.69 & 2.55 & 2.40 & 1.91 & 1.73 & 1.53 & 1.38 \\
\hline 60 & 3.62 & 3.22 & 3.08 & 2.93 & 2.44 & 2.26 & 2.06 & 1.91 \\
\hline 80 & 4.95 & 4.55 & 4.41 & 4.26 & 3.77 & 3.59 & 3.39 & 3.24 \\
\hline 95 & 5.31 & 4.91 & 4.77 & 4.62 & 4.13 & 3.95 & 3.75 & 3.60 \\
\hline 99 & 5.58 & 5.18 & 5.04 & 4.89 & 4.40 & 4.22 & 4.02 & 3.87 \\
\hline Top & 5.77 & 5.37 & 5.23 & 5.08 & 4.59 & 4.41 & 4.21 & 4.06 \\
\hline
\end{tabular}

6 give the capital costs associated with the two forms of tenure-that is, the cost of the invested and borrowed capital and the cost of depreciation, plus net taxes. Other costs of housing-such as maintenance of the building, utilities, and other services-are not included here since their aftertax cost should be the same whether an individual owns or rents. Moreover, these calculations do not capture transaction costs of the types 
surveyed in Section II, which, as we have seen, may be affected by tenure choice.

Because the cost of housing for an owner-occupant depends on the owner's tax bracket, and the cost of rental housing similarly depends on the landlord's tax bracket, the different columns in Table 6 give a series of eight different cost figures for both ownership and rental for each year to reflect different tax brackets. The tax brackets chosen for each year were those given in Table 4, corresponding to different points in the income distribution. The columns of Table 6 correspond to the columns in Table 4. For example, the first column gives figures for individuals who are in the tax bracket corresponding to a household income representing the twentieth percentile of the income distribution, while the last column gives figures for individuals who are in the top marginal tax bracket.

The figures in part A of Table 6 are computed on the assumption that the minimum tax is not binding on the landlord during the years in which that tax was in effect (1976 and 1985). Part B of Table 6 gives alternative figures for the latter years, computed with the assumption that the minimum tax was binding on the landlord. As part B shows, the minimum tax raises the landlord's cost substantially.

To find an individual's cost of ownership for a given year from Table 6, one simply looks at the column corresponding to the individual's position in the income distribution. On the other hand, while the rows labeled "rent" in Table 6 similarly give the landlord's cost as a function of her tax bracket, this does not necessarily become the tenants' cost. If, as seems plausible, the market for rental apartments is reasonably competitive, then market forces will drive rents to equal the cost (as given in Table 6) for the marginal landlord-that is, the landlord with the highest cost among those who remain in the market when supply equals demand. And the landlord with the highest cost is the one in the lowest tax bracket. ${ }^{58}$ Consequently, the cost of rental to the renter for a given year is given by the figure in Table 6 for that tax bracket that is the tax bracket of the marginal landlord. Landlords in higher tax brackets will be earning pure profits, while those in lower brackets will be driven from the market.

Unfortunately, we have no reliable empirical data on the tax bracket of marginal landlords. Because of the ease of syndicating investments in real estate through limited partnerships, however, it is reasonable to assume that, at least for large or luxury apartment buildings prior to the

\footnotetext{
58 The term "landlord" is used here to refer collectively to the owners of a building, which will often include a number of investors acting as limited partners. The relevant tax bracket is the tax bracket of the investors.
} 
Tax Reform Act of $1986,{ }^{59}$ this bracket was relatively high ${ }^{60}$ In any event, the columns of Table 6 permit one to see the effect on market rents of different assumptions about the tax bracket of marginal landlords.

Examination of Table 6 shows that the after-tax cost of housing has changed considerably over the years for both rental and owner-occupancy, in large part as a result of changes in the tax regime. For example, we can see that the substantial tax subsidies built into the personal income tax have generally made housing substantially less expensive, for both renters and owners, in the postwar years than it was in the 1930s. Also, comparison of the figures for 1985 and 1988 shows that the Tax Reform Act of 1986 should in most cases have significantly increased the cost of housing for both renters and owners. Such changes in themselves, however, are not our primary concern here. Rather, we are concerned with the difference between the cost of renting and the cost of owning and with the changes in that difference over time.

The figures in Table 6 permit us to observe that difference-that is, to compare the after-tax cost to an individual of occupying the same apartment when it is $(a)$ in a building organized on a rental basis and $(b)$ in a building organized as a condominium or cooperative. To make the comparison for a given year, one simply compares $(a)$ the figure in the "rent" row in the column corresponding to the marginal landlord's position in the income distribution with $(b)$ the figure in the "own" row corresponding to the individual's position in the income distribution.

Table 7 gives these differences for the years and the tax brackets reflected in Table 6. To take an example, consider the figures in Table 7, part A, for 1976; they show that an individual who is in the eightieth percentile of the income distribution would face an annual cost of housing that is lower by .47 percent of the market value of the living unit if he were to own the unit rather than rent it and if the tax bracket of marginal landlords were that of persons in the ninety-fifth percentile of the income distribution. Since, from Table 6, part A, the annual cost of renting from such a landlord would be 1.45 percent of the market value of the unit, this represents a saving of 32 percent over the cost of rental. (Again, we

\footnotetext{
59 It is possible that, at least for buildings below a certain scale, landlords are often of a socioeconomic status not far removed from that of their tenants. This is likely to be the case, for example, where there are substantial economies from having the owner reside in or near the building. As a result, the marginal tax bracket for landlords of such buildings might be lower than that for landlords of large or luxury buildings.

${ }^{60}$ The marginal bracket for landlords may, however, nevertheless be lower than the top bracket or even that of the ninety-ninth percentile of the household income distribution. For example, the tax rate at which the after-tax interest on municipal bonds equals that on comparable taxable bonds has generally been well below the maximum bracket, indicating that the marginal investor in such bonds is not in the top bracket.
} 
TABLE 8

Savings from Owner-occupancy When Marginal Landlord and Owner-Occupant Are Both in Ninety-fifth Percentile

\begin{tabular}{|c|c|c|c|c|c|c|}
\hline & \multicolumn{3}{|c|}{ Without Minimum Tax } & \multicolumn{3}{|c|}{ With Minimum Tax } \\
\hline & $\begin{array}{c}\text { Savings } \\
\text { from } \\
\text { Table } 7, \\
\text { Part A }\end{array}$ & $\begin{array}{c}\text { Rent } \\
\text { from } \\
\text { Table 6, } \\
\text { Part A }\end{array}$ & $\begin{array}{c}\text { Savings } \\
\text { as \% } \\
\text { of Rent }\end{array}$ & $\begin{array}{c}\text { Savings } \\
\text { from } \\
\text { Table 7, } \\
\text { Part B }\end{array}$ & $\begin{array}{c}\text { Rent } \\
\text { from } \\
\text { Table 6, } \\
\text { Part B }\end{array}$ & $\begin{array}{c}\text { Savings } \\
\text { as \% } \\
\text { of Rent }\end{array}$ \\
\hline 1936 & .00 & 5.08 & 0 & $\ldots$ & $\ldots$ & $\ldots$ \\
\hline 1946 & .66 & 3.78 & 17 & & $\ldots$ & $\ldots$ \\
\hline 1956 & 1.44 & 6.67 & 22 & $\ldots$ & $\ldots$ & $\ldots$ \\
\hline 1966 & 1.48 & 5.92 & 25 & $\ldots$ & $\ldots$ & $\ldots$ \\
\hline 1976 & 1.11 & 1.45 & 77 & 2.10 & 2.44 & 86 \\
\hline 1985 & 2.95 & 6.38 & 46 & 3.95 & 7.38 & 54 \\
\hline 1988 & 3.18 & 8.83 & 36 & $\ldots$ & $\ldots$ & $\ldots$ \\
\hline
\end{tabular}

are speaking here of capital costs; the savings as a percentage of the total market rental cost would be smaller.) Or, put in dollar terms, the annual savings on an apartment with a market value of $\$ 100,000$ would be $\$ 470 .^{61}$

A clear measure of the pure tax subsidy to owner-occupancy is offered by the figures on the diagonals in Table 7 , giving the cost difference when the occupant and the marginal landlord are in the same tax bracket. The first column in Table 8 restates these figures for the tax bracket corresponding to the ninety-fifth percentile of the income distribution. The third column in Table 8 gives the cost savings from owner-occupancy as a percentage of the capital cost of renting (col. 2). The fourth through sixth columns give the corresponding figures under the assumption that the minimum tax applies. From the figures in the third column, we see that the percentage savings goes from zero in the 1930s, to a peak of over 77 percent in 1976, and then falls off somewhat after that. The absolute dollar savings from owner-occupancy, on the other hand, reaches its peak in 1988, when (as shown by the first column) it amounts to an annual saving equal to 3.18 percent of the value of the housing unit (or $\$ 3,180$ on a unit costing $\$ 100,000) .{ }^{62}$ If the minimum tax is binding on marginal

61 The calculations of tax savings from owner-occupancy presented here are reasonably robust. Computations of the sensitivity of the results to differing assumptions concerning a variety of variables, including interest rates and expected inflation, show that the net tax savings from owner-occupancy in any given year is not much affected by these assumptions, with the exception of expectations concerning housing price increases, which are discussed in the following note.

62 The computation of tax savings offered here, it should be noted, is probably conservative for recent years. In particular, the calculations have been made on the assumption that potential purchasers of housing foresaw none of the unusually rapid increase in housing 
landlords, then the savings are even more dramatic in 1976 and 1985, as the last three columns show.

Although the percentage savings reported in the third and sixth columns of Table 8 are impressive-amounting to between 77 percent and 86 percent of the capital cost of housing in 1976-the absolute dollar savings from owner-occupany (as reflected, for example, in the first and fourth columns of Table 8) is probably more important for the purpose at hand. The question here is whether the tax subsidy to owner-occupancy as opposed to rental is large enough to dominate, for a significant share of housing market participants, any other costs (of the type discussed in Section II above) that would otherwise lead to the choice of rental rather than ownership. Those other costs are likely to be only partially proportional to the capital cost of housing.

To judge more clearly the magnitude of this tax subsidy for cooperatives and condominiums, imagine that a new apartment building was constructed in 1985 with 100 units, at a cost of $\$ 150,000$ per unit (or $\$ 15$ million in total). Using the figures from Table 8, aggregate tax savings of $\$ 442,500$ per year $(\$ 592,500$ if the minimum tax were applicable) would have been expected for the building as a whole if the developer sold off the apartments as condominium units rather than retaining title to the building and renting out the apartments.

\section{Implications for the Spread of Cooperatives and Condominiums}

Over the fifty-year period covered by Table 7 there has been a clear progression toward stronger tax subsidies for owner-occupied as opposed to rental housing. In 1936, there was a net tax subsidy in favor of ownership only for housing occupants in the top 1 percent of the income distribution, regardless of the landlord's tax bracket, and that subsidy was substantial only for the small number of individuals in the very highest marginal brackets. ${ }^{63}$ By 1956, there was a net subsidy in favor of owner-

prices that occurred in the 1970 s but, rather, assumed that housing prices would just keep pace with the overall inflation rate. Hendershott \& Shilling, supra note 51 , based their calculations on the alternative assumption that consumers expected housing prices to continue to follow the trend of the recent past. This is one important reason why they show a larger savings from owner-occupancy than is reflected in the figures presented here. The expected savings from owner-occupancy shown here would be considerably larger for the 1970 s if consumers were assumed to have correctly anticipated that housing prices would increase substantially in the future.

${ }^{63}$ Table 7 shows a net subsidy to ownership over rental for occupants in all income classes when the landlord is in the top tax bracket. But this is a consequence of the higher taxes paid by a landlord in that bracket rather than a subsidy to ownership; consequently, there would be no incentive for individuals in the top tax bracket to serve as landlords, and the right-hand column in Table 7 can be ignored for 1936 . 


\section{TABLE 9}

Net Tax Subsidy and Construction Data for 1970-86 (with Minimum Tax)

\begin{tabular}{lrrcc}
\hline \hline Year & Rent & Own & $\begin{array}{c}\text { Difference } \\
\text { (Rent - Own) }\end{array}$ & $\begin{array}{c}\text { Ratio of Condo } \\
\text { and Co-op Units } \\
\text { to Total Units }\end{array}$ \\
\hline 1970 & 4.27 & 2.95 & 1.32 & N.A. \\
1971 & 3.85 & 2.74 & 1.11 & N.A. \\
1972 & 4.87 & 3.51 & 1.36 & N.A. \\
1973 & 5.57 & 4.07 & 1.50 & .19 \\
1974 & 3.67 & 2.55 & 1.12 & .29 \\
1975 & 1.89 & .90 & .99 & .17 \\
1976 & 2.44 & .98 & 1.46 & .17 \\
1977 & 2.01 & .98 & 1.03 & .14 \\
1978 & 2.34 & .95 & 1.39 & .28 \\
1979 & .43 & .13 & .30 & .34 \\
1980 & -.20 & -.48 & .28 & .38 \\
1981 & .90 & .80 & .10 & .32 \\
1982 & 4.46 & 3.09 & 1.37 & .31 \\
1983 & 6.16 & 4.39 & 1.77 & .19 \\
1984 & 7.67 & 5.79 & 1.88 & .21 \\
1985 & 7.38 & 4.67 & 2.71 & \\
1986 & 6.31 & 4.09 & 2.22 & \\
\hline
\end{tabular}

NotE. - N.A. $=$ not available.

ship in nearly all cases except when the landlord was in the top tax bracket. By 1966 and 1976 (using part B of Table 7), this net subsidy had broadened further to include all cases in which the potential landlord and occupant were in the same tax bracket. Finally, by 1988 there was a substantial net tax subsidy in favor of ownership in all cases. This pattern of development corresponds, in general terms, with the evolution of condominium and cooperative housing. In the 1930s, such housing was largely confined to the luxury market. The market share of cooperatives then grew, though at a modest pace, through the 1950 s and was supplemented by the condominium form in the 1960 s. Thereafter, the two forms together spread with increasing rapidity.

On the other hand, for some shorter intervals within this broad fiftyyear period, the correlation between the net subsidy to ownership and the rate of formation of cooperatives and condominiums is poor. In particular, although the major increase in the rate of formation of cooperatives and condominiums occurred in the middle 1970s, the net tax subsidy was not generally stronger then than it was in 1966 and, except for landlords in the very top tax bracket, was not markedly stronger than it was even in 1956. Moreover, if we look at annual data for more recent years, the correlation is even worse. Table 9 gives, for 1970-86, annual figures 


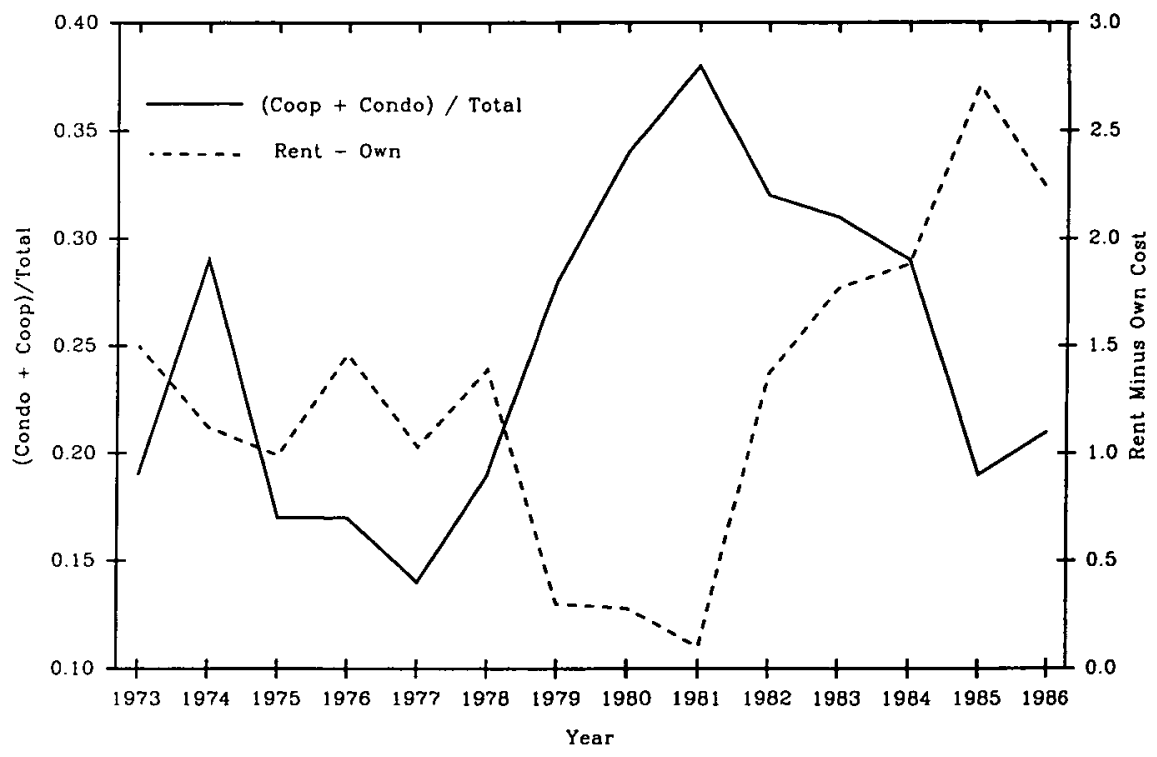

Figure 1.-Net tax subsidy and new construction, 1973-86

for the net tax subsidy to ownership as well as the percentage of new construction of multiunit housing represented by cooperatives and condominiums; the data are graphed in Figure 1. As the latter figure shows, for this period the rate of formation of cooperatives and condominiums correlates negatively, if at all, with the net subsidy to ownership. This is confirmed by statistical analysis, which shows a negative coefficient when the rate of formation of cooperatives and condominiums is regressed against either current or lagged figures for the net tax subsidy. ${ }^{64}$

Consequently, if tax subsidies have been an important inducement to the development of condominium and cooperative housing, the effect must have been long-term and slow acting. Before we can draw further

\footnotetext{
64 When the figures in the last column of Table 9 (ratio of condominium and cooperative units constructed during the year to total multiunit housing units constructed) are regressed against the figures in the second to last column ("Difference"-that is, the difference between the rent and own cost, or the net tax subsidy to ownership) plus a constant, the coefficient is negative whether the difference figure chosen is that for the current year or is lagged one or two years - though it is (just barely) significant at the 5 percent level only when the Difference variable is lagged two years. (The rent cost figures in Table 9 assume that the minimum tax applies to the landlord. If, alternatively, the minimum tax is omitted in computing the rental cost, then the regression coefficient for Difference is significant at the 5 percent level when the Difference variable is lagged either one or two years, though the magnitude of the coefficient remains roughly the same.)
} 
conclusions concerning the effects of tax subsidies, however, we must examine other developments that may have affected supply and demand for owner-occupied apartments, including changes in some of the costs surveyed in Section III.

\section{Other Financial Influences}

\section{A. Rent Control}

Rent control creates a strong incentive for adopting the cooperative and condominium forms as means of securing a higher rate of return on apartment buildings. However, rent control can quickly be dismissed as a direct cause of the recent spread of cooperatives and condominiums in general. Only a small minority of those American cities that have experienced a recent surge in cooperatives and condominiums have rent control. ${ }^{65}$ Indeed, at least so far as conversions from rental to ownership are concerned (as opposed to new construction), jurisdictions with rent control seem to experience less activity than noncontrolled jurisdictions. ${ }^{66}$

On the other hand, it is possible that the fear of rent control has provided at least some of the incentive for the recent surge in condominiums. In the past twenty years, rent control has begun to spread at a rapidly accelerating pace through American jurisdictions. ${ }^{67}$ This development, together with the adoption of rent control throughout much of Western Europe in this century, may serve to discourage many potential landlords.

\section{B. Increasing Liquidity}

The increase in popularity of apartment ownership in recent years might be thought attributable, in part at least, to an increase in liquidity among apartment dwellers that permitted a greater proportion to invest the equity necessary for ownership.

For the population at large, however, a direct correlation between

${ }^{65}$ HUD, supra note 7, at ii.

${ }^{66}$ For example, Chicago, which does not have rent control, had a far higher rate of conversion over the period 1970-79 (5.44 percent of the rental housing stock) than did New York City (.58 percent), which does. The reason for this pattern may be that jurisdictions with rent control have sought to protect those controls by adopting stricter regulation of conversions than have jurisidictions without rent control. Id. at app. 1, 10-11.

${ }^{67}$ Although in 1970 New York City was evidently the only American city with rent control, by 1979 rent control had been adopted in at least 250 local jurisdictions. Major cities with some form of rent control today include Los Angeles, San Francisco, Boston, and Washington, D.C. Charles Baird, Rent Control: The Perennial Folly (1980); National Multi Unit Housing Council, The Spread of Rent Control (1982). 


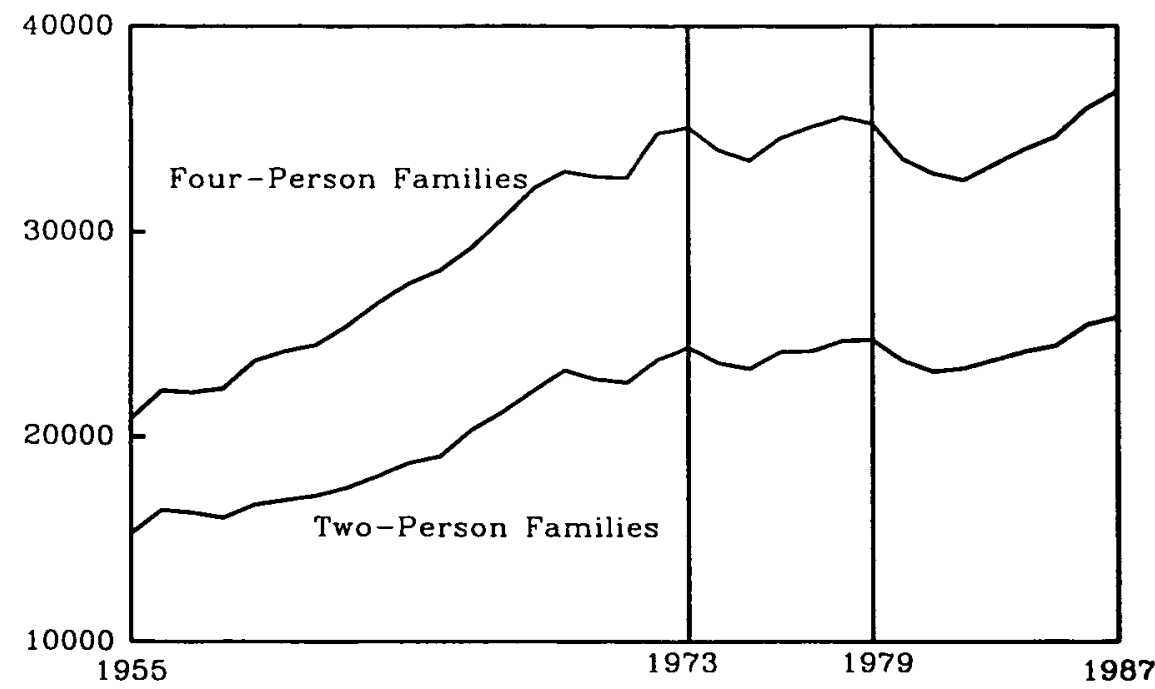

Figure 2.-Median income of two-person and four-person families in constant (1987) dollars, 1955-87.

household income and changes in the market share of owner-occupied apartments is lacking. As Figure 2 shows, in the middle and late 1970s, when apartment ownership first began to spread rapidly, there was virtually no overall growth in real family income, in sharp contrast to the preceding two decades ${ }^{68}$ Moreover, housing prices increased in the $1970 \mathrm{~s}$ more rapidly than inflation in general, in contrast to the experience of the two preceding decades, thus increasing the price of housing relative to household income. ${ }^{69}$ At best it can be argued that the spread of apartment ownership in the 1970s was a delayed response to the increased liquidity resulting from growth in household income in earlier decades-the delay perhaps being caused by the need to develop and become familiar with the condominium form. ${ }^{70}$

Alternatively, special factors could have led to increased liquidity among apartment occupants as opposed to the general population. For example, it seems likely that in the late 1960s and 1970s there was a substantial increase in the general liquidity of the elderly owing to the

68 For the period 1970-86, median household income, measured in constant 1986 dollars, reached its highest value $(\$ 25,936)$ in 1973 and declined to its lowest value $(\$ 22,913)$ in 1982 ; in 1979 it was $\$ 24,866$. U.S. Bureau of the Census, Statistical Abstract of the United States: 1988, table 691 (1987).

69 See Hendershott \& Shilling, supra note 51.

70 See Sec. VI infra. 
combined accumulated influence of pension funds and social security, and this may have led to an increase in the demand for condominiums among that subset of the population. ${ }^{71}$ It is also sometimes said that the 1970s saw the advent of a large new class of highly liquid apartment dwellers consisting of the relatively affluent childless young households resulting from the increasing tendencies for marriage and childbearing to be postponed and for women to enter the work force. It is difficult to locate sufficient demographic data on occupants of apartments to assess this latter argument, although it is questionable that any such demographic shift could have been so pronounced as to correlate well with the rapid expansion of cooperative and condominium housing in the 1970s.

Moreover, there is another consideration that argues in general against increasing liquidity as an important cause of the growing market share of cooperatives and condominiums. This market share increased rapidly during the late 1970s, just as inflation rates were becoming exceptionally high. Yet a high rate of inflation seriously aggravates liquidity problems for many prospective homeowners because it increases substantially the nominal interest payments on mortgages, effectively making the borrower repay the principal much faster than otherwise and requiring a large annual outflow of cash. ${ }^{72}$

In addition, throughout this century there have been substantial numbers of apartment dwellers who were quite prosperous and yet, until the recent past, rented; for these individuals, at least, liquidity must not have been constraining.

\section{Mortgage Insurance}

Another factor affecting the liquidity of occupants of apartment buildings has been the advent of federal mortgage insurance. Federal Housing Administration (FHA) mortgage insurance, which was first made available for single-family dwellings in the 1930 s, was extended to the construction and purchase of cooperative apartments in $1950^{73}$ and to condominiums in $1961 .^{74}$

This program has not directly affected the incentives for lending to

\footnotetext{
71 On the other hand, the adoption in 1963 of the onetime forgiveness of accumulated capital gains from the sale of a personal residence for taxpayers over 55 years of age presumably made it easier for many elderly persons to sell the large houses in which they had raised children and rent an apartment unit rather than remain owners.

72 It would be otherwise if repayments of principal on home mortgages were indexed for inflation, but this has generally not been the practice.

${ }^{73}$ National Housing Act of $1950, \S 213$.

74 Housing Act of $1961, \S 104,75$ stat. 160 (adding $\S 234$ to the National Housing Act).
} 
cooperatives and condominiums in any significant degree. To begin with, FHA mortgate insurance has been sold at a rate that is remunerative for the government and thus has not provided a subsidy for owner-occupancy as opposed to rental. ${ }^{75}$ Moreover, the numbers of units insured have been only a small fraction of the total constructed or converted. ${ }^{76}$

The advent of FHA mortgage insurance may, however, have had an indirect effect in easing credit for purchase of apartments. After the Depression of the $1930 \mathrm{~s}$, when many cooperatives failed, cooperatives were widely thought to be unusually risky borrowers because of the commonproperty feature of the mortgage. ${ }^{77}$ Condominium developments, in turn, were novel when first introduced, and lenders might well have been wary of them. The availability of FHA mortgage insurance presumably helped allay such fears by essentially eliminating the risk of default in return for a modest premium. But the effect of the insurance may well have been felt too by projects that were not federally insured. The FHA's willingness to insure such projects may have generated confidence in the forms by itself. Moreover, the low default rates on insured projects presumably helped demonstrate to lenders that owner-occupied apartment units were not unusually risky and, thus, were worth lending to even in the absence of federal insurance (which, with its flat fee structure, is relatively costly in cases in which the borrower can provide reasonable security). Federal mortgage insurance had a strong demonstration effect of this sort for single-family houses in the 1930s when the advent of such insurance, even though unsubsidized, led to a substantial easing in the terms of residential mortgages in general, including significantly longer repayment periods and lower down payments. ${ }^{78}$ Yet federal mortgage insurance became available for cooperatives and condominiums long before the marked expansion in the market share of those forms. Consequently, any such demonstration effect was evidently modest. ${ }^{79}$

75 See Henry Aaron, Shelter and Subsidies 77-79, 176-99 (1972); see also Donald Cunningham \& Patric Hendershott, Pricing FHA Mortgage Default Insurance, 3 Housing Fin. Rev. 373 (1984).

76 From 1961-86, the FHA insured a total of 60,296 mortgages for the purchase of condominium units by individuals and insured as well mortages for the purchase or construction of buildings for development as condominiums containing a total of 27,452 units. Telephone interview with Robert Sacrey, chief management information specialist for Single Family Insured Activity, Federal Housing Administration (November 1986). This compares with a total stock of 1,389,000 condominium units in 1983. See Table 1 supra.

${ }^{7}$ See Twentieth Century Fund, supra note 3, at 234.

78 Aaron, supra note 75, at 74-90.

79 The federal government has also facilitated the secondary mortgage market through the Federal National Mortgage Association, which was established in the 1930s to purchase FHA insured mortgages and which more recently has purchased conventional mortgages 


\section{Summary}

In sum, the threat of rent control, increases in liquidity among apartment dwellers, and the advent of mortgage insurance may all have helped to reduce the cost of owner-occupied vis-à-vis rented apartments in recent decades. The nature and timing of each of these developments, however, provides reason to believe that none of them has had more than a modest effect in this respect.

\section{Organizational InNovation}

Another possible explanation for the recent spread of condominiums is that the condominium form, when first introduced to American law in the early 1960 s, constituted an organizational innovation that reduced the cost of owner-occupancy in multiunit dwellings significantly below that afforded by cooperatives and thus made owner-occupancy efficient for a much larger segment of the apartment market than it had been previously.

This explanation, which we can label the "organizational innovation theory," has some plausibility. By minimizing the common-property element in ownership and leaving each occupant to seek separate financing for her individual unit, a condominium, in contrast to a cooperative, reduces the extent to which the occupants of a building must serve as sureties for each other. Consequently, a condominium has better risksharing properties than a cooperative and is also less prone to the prospect that default by some of the building's occupants will lead to default and dislocation for the rest owing to the latter's limited liquidity. Moreover, in a cooperative as opposed to a condominium a member is (or was until recently) constrained to the same level of debt financing as the other members. If the collective mortgage represents only 40 percent of the current market value of the building, then a new tenant can in effect borrow no more or less than 40 percent of the cost of purchasing her unit. ${ }^{80}$

On the other hand, occupants of a cooperative benefit from the savings that result from having only one large mortgage on a building rather than the many individual ones that must each be renegotiated each time a condominium unit changes hands. Furthermore, members of a coopera-

as well. Id. The Federal National Mortgage Association includes mortgages on cooperative and condominium housing among those it will purchase. But this program, too, is largely unsubsidized and, presumably, has at most indirect effects on the availability of credit for owner-occupied apartments.

${ }^{80}$ This constraint has been relaxed recently as banks have begun to make personal loans secured by an individual tenant's shares of stock in a cooperative apartment building. 
tive may be less prone than members of a condominium to opportunistic default owing to their sense of obligation to their fellow tenants.

Consequently, it is not clear a priori that condominiums are markedly more efficient than cooperatives. Moreover, the process by which the condominium form has spread raises three objections to the organizational innovation theory.

\section{A. Why Was the Condominium Form Not Adopted Earlier?}

The condominium form is an import from Europe, where it has been known for centuries. ${ }^{81}$ If condominiums are significantly more efficient than cooperatives, then why was the form not imported to the United States much earlier than the 1960s?

There may be a response to this objection. Arguably it is only recently-since the 1930s-that the European states have adopted condominium statutes that provide an adequate model for importation to the United States. ${ }^{82}$ Consequently, modern enabling statutes for condominiums may have come to the United States not much later than they did to Europe, constituting a more or less simultaneous legal innovation on the two continents. In any event, we know too little about the mechanics of legal transfers to infer that, simply because a legal form was slow in crossing the Atlantic, it did not represent an important improvement in efficiency.

The actual circumstances surrounding the enactment of condominium statutes in the United States shed little further light on this issue. In fact, the statutes were not directly imported from Europe but came to the mainland United States by a slow and circuitous path that led through Latin America and Puerto Rico and that appears to have been largely fortuitous. The critical event that stimulated the adoption of condomin-

${ }^{81}$ It is interesting, and relevant for present purposes, to ask why the condominium form came to be employed in Europe earlier than it did in the United States. The answer to this question for the nineteenth century and before is unclear. It seems, however, that the great boom in condominium development in Europe came only after the First World War and was in considerable part a response to the rent controls that began to be widely adopted in Europe at that time. J. Leyser, Ownership of Flats-a Comparative Study of Flats, Int'l \& Comp. L. Q. 31, 32 (1958); Terence Burke et al., Condominium: Housing for Tomorrow 7 (1964).

82 For example, in France, where condominiums had been known since the Middle Ages and recognized to some degree by statute since the Code Napoleon of 1804, it was not until 1938 that legislation was enacted that specified in any detail the rights and obligations of the unit owners. The first modern condominium statute was adopted in Belgium in 1924; Italy and Spain, like France, adopted their modern condominium legislation in the 1930s, while Germany and the Netherlands did not do so until the 1950s. L. Neville Brown, French Co-property Apartments: A Model for English Law? 110 Solic. J. 591 (1966); Leyser, supra note 8, at 35; Ferrer \& Stecher, supra note 8, at 14-40. 
ium statutes by the American states-namely the extension of FHA mortgage insurance to condominium units in 1961-was a response to lobbying by interests in Puerto Rico, which had long had the condominium form; it was not actively supported by housing developers, financers, or consumers in the continental United States, thus suggesting that the condominium form was not then perceived by the real estate community as offering important efficiency advantages-although this might, of course, have simply reflected their inexperience with the form. ${ }^{83}$ (It is, incidentally, clear that American legal scholarship played no important role in the condominium innovation; there appear to be no articles in U.S. legal periodicals dealing with condominiums between 1930 and 1960.)

\section{B. Why the Lag in Condominium Development?}

A second objection to the organizational innovation theory is, If the condominium form constituted a conspicuous reduction in the cost of owner-occupancy for apartments, why did a decade elapse between the adoption of condominium statutes and the time when condominiums began to be developed in substantial numbers? This delay suggests that the efficiency advantages of condominiums over cooperatives may be relatively modest and that it was not until the 1970 s, when the tax subsidy to owner-occupied apartments became exceptionally large, that widespread development of either cooperatives or condominiums became worthwhile. Then, owner-occupied apartments having finally become remunerative for a significant portion of the market, the condominium

${ }^{83}$ A condominium enabling act had been adopted in Puerto Rico as early as 1901 and revised in 1951; it was not until 1958, however, that a truly workable statute was fashioned. P.R. Civ. Code $\S 403$ (1902); P.R. Laws Ann. tit. 31, § 1275 (1954); P.R. Laws Ann. tit. 31, $\S 1291$ et seq. (1958). The Puerto Rican statutes were patterned after those adopted in various Latin American countries, which in turn were influenced by the European, and particularly the Spanish, condominium statutes. See Ferrer \& Stecher, supra note 8, at 51. (The 1958 statute, in particular, was modeled after an earlier Cuban act. W. Robert Folkes, Legal and Practical Aspects of Condominiums, 19 Bus. Law. 233 (1963).) Then, evidently influenced by lobbying from Puerto Rican banking and real estate interests, who were seeking to improve financing for the condominium housing that was already being developed in Puerto Rico, Congress in 1961 approved FHA insured mortgages for condominiums; to implement this, the FHA promulgated a model condominium act that essentially followed the Puerto Rican statute. See U.S. House of Representatives, Hearings on General Housing Legislation before the Subcommittee on Housing of the House Committee on Banking and Currency, 86th Cong., 2d Sess. 246-74 (1960); Aaron M. Schreiber, The Lateral Housing Development: Condominium or Home Owners Association? 117 U. Penn. L. Rev. 1104 , 1110 (1969). Within a few years, most states proceeded to adopt a condominium statute based on the FHA model, though perhaps in considerable part only because this was a costless measure that might make state residents eligible for additional federal mortgage insurance and thus gave the appearance of addressing housing problems. 
rather than the cooperative form was generally chosen because of the two it was marginally-but only marginally-more efficient.

But this objection, too, is not decisive. Even industrial process innovations, whose diffusion rates have been widely studied, commonly exhibit a lag of some years between introduction and widespread adoption. ${ }^{84}$ And an organizational innovation such as condominium housing, in contrast to industrial process innovations, requires not only that producers (in this case, developers) come to understand the advantages of the new form and the means of implementing it, but that lenders, brokers, and consumers also come to understand and trust it. Consumers, in particular, must come to believe that there will be a resale market for their units, which requires a substantial act of faith before that market has actually developed. A delay of a decade between the appearance of the innovation and its widespread adoption is therefore not necessarily evidence that the innovation did not represent a significant reduction in costs.

\section{Why So Many Cooperatives in New York City?}

The third and most telling objection to the organizational innovation theory is that in New York City there are still nearly five times as many cooperative units as there are condominium units $;{ }^{85}$ moreover, new cooperatives continue to be formed in New York City, through new construction and (primarily) conversion, in significantly larger numbers than condominiums. ${ }^{86}$ Presumably an important explanation for this is that New York consumers, lawyers, lenders, and real estate agents accumulated substantial experience with cooperatives through their relatively extensive development there-evidently as a response to rent control-between 1945 and 1965. This experience, which was lacking in other jurisdictions, apparently gave cooperatives a continuing transaction cost

${ }^{84}$ See Edwin Mansfield, Industrial Research and Technological Innovation (1968); Lars Nasbeth and George F. Ray, The Diffusion of New Industrial Processes (1974); Stephen Davies, The Diffusion of Process Innovations (1979).

${ }^{85}$ As of 1986 there were 57,000 condominium units in New York City $(28,000$ from conversion and 29,000 from new construction) and 246,000 cooperative units $(117,000$ from conversion and 19,000 from new construction). The latter figures exclude an additional 83,000 cooperative units that receive public subsidies under various programs. New York State Dep't of Public Service, Office of Energy Conservation and Environmental Planning, New York City Housing Market (April 1986).

${ }^{86}$ In 1987 there were a total of 35,619 cooperative units created $(34,450$ through conversion and 1,169 through new construction) in contrast to 9,479 condominium units $(2,188$ through conversion and 7,291 through new construction). Id. There are evidently no special regulatory restrictions in New York City on the conversion of rental units to the condominium rather than the cooperative form that would in themselves account for the disproportionately large number of cooperative units formed there through conversion. Interview with Gary Glatter, associate general counsel, M. J. Raines Company (May 15, 1989). 
advantage over condominiums even after the latter form became available. If condominiums were significantly more efficient than cooperatives as an organizational form, it seems unlikely that such familiarity would in itself have been sufficient to cause cooperatives to continue to dominate the market for a quarter of a century after condominiums became available. This conclusion is reinforced by the fact that, as discussed below, in New York City cooperatives and condominiums have appeared in roughly equal numbers among commercial buildings even though nearly all of them were formed since 1978, by which time the condominium form was quite well established in the New York residential market. If condominiums were significantly more efficient than cooperatives, one would have expected only condominiums among these commercial buildings.

These developments in New York City suggest that it is quite possible that, had condominium statutes never been adopted in the United States, many of the buildings organized as condominiums in the past two decades, not only in New York but throughout the country, would have been organized as cooperatives instead and that the total market share of owner-occupied apartments would still have grown roughly as it did.

\section{Commercial Condominiums and Cooperatives}

Even more persuasive evidence that the recent spread of cooperatives and condominiums is primarily a response to tax incentives, and not to other developments such as those just surveyed, comes from the remarkable paucity of commercial buildings organized as cooperatives or condominiums.

\section{A. The Absence of Commercial Development}

Twenty years ago, when condominiums were still new, it was widely thought that they would see their greatest growth in the commercial sector. ${ }^{87}$ Yet this has not occurred. Commercial cooperatives and condominiums remain a rarity; multiunit commercial buildings are still almost universally organized on a rental basis. ${ }^{88}$ In New York City, for example, despite the extensive development of both cooperatives and condomini-

87 I Rohan \& Reskin, supra note 43, at 3.

88 It was estimated in 1981 that there were then only 400-600 commercial condominiums in the United States. Outlook for Commercial Industrial Condominiums, Mortgage \& Real Est. Executives Rep., April 1, 1981, at 5, cited in Note, Commercial Condominiums: Statutory Roadblocks to Development, 34 U. Fla. L. Rev. 432, 433 n. 8 (1982). (Despite the title of the latter article, there seem to be no significant statutory obstacles to the formation of office condominiums in most states.) 
ums in the residential sector, there was evidently only one office building organized as a condominium before 1978, and there were none organized as cooperatives. Since then, the rate of formation (primarily through conversion) of office cooperatives and condominiums has increased; nevertheless, as of December 1984 there were still only sixty such buildings in New York City in total, divided roughly equally between cooperatives and condominiums. ${ }^{89}$ And this was true despite the fact that office cooperatives and condominiums escape New York City's commercial rent tax. ${ }^{90}$

So long as everyone is in the same tax bracket, the International Revenue Code is essentially neutral between owner-occupancy and rental in commercial buildings, in contrast to the previously described situation with residential buildings. On the other hand, there is some tax bias when tax brackets differ between occupants and potential landlords. For those years in which depreciation deductions have substantially exceeded economic depreciation, it has been advantageous to have a commercial building owned by someone who is in a high tax bracket and who can therefore take advantage of the large depreciation deductions to shelter other income that would otherwise be taxed at a high marginal rate. Occupants in low tax brackets have therefore had an incentive to lease rather than own.

An estimate of the magnitude of this incentive can be derived from Table 6, part A. In 1976, for example, there was a potential annual tax saving of 1.2 percent of the building's value if an occupant in a tax bracket corresponding to the fortieth percentile in the income distribution decided not to own but rather to rent from a landlord in the ninety-fifth percentile, and 4.6 percent if the landlord was in the top tax bracket. Evidently cooperative and condominium ownership has insufficient efficiency advantages over rental, if any, to overcome such a subsidy.

Many commercial tenants occupy their space for relatively long periods of time, so that the transaction costs of moving are presumably not a more important consideration for them than for the typical owner of a residential cooperative or condominium. Moreover, businesses seem likely, on average, to have as much or more need than households to modify the space they occupy to suit their special requirements. For example, shops frequently remodel their display space elaborately, and even law firms and other consumers of office space commonly move walls, install paneling, or reconfigure utilities to meet their individual needs. Likewise, businesses seem as well suited as households to bear

\footnotetext{
${ }^{89}$ Golda Housman, Office Condominiums and Cooperatives: Manhattan's Underground Success Story, 15 Real Est. Rev. 71 (Fall 1985).

${ }^{90}$ Id.
} 
the risks associated with ownership-perhaps rather better suited, on average. Nor is it apparent that businesses suffer from greater liquidity problems than do households. In short, tax considerations aside, there seems as much or more incentive for businesses to own the space they occupy in multiunit commercial buildings as there is for apartment dwellers to own their apartments.

Like households, businesses frequently own the building they occupy if they are the sole occupant. This suggests that the lack of commercial cooperatives and condominiums may be attributable in substantial part to the costs of collective governance where interests are heterogeneous. Further evidence of this comes from observing the types of situations in which commercial condominiums typically arise. Doctors' offices seem to be among the most common. ${ }^{91}$ One reason for this is presumably that doctors are frequently in high tax brackets and thus can make good use of the tax shelter advantages of owning commercial real estate. But another may be that doctors have relatively homogeneous interests when it comes to renting office space, so that serious conflict in decision making is relatively infrequent. Other types of commercial tenants, in contrast, can be quite heterogeneous in their needs ${ }^{92}$ and in general are probably more so than residential tenants.

\section{B. Tax Forms versus Contractual Forms}

For tenure choice in residential versus commercial buildings, the divergent incentives created by tax law run counter to the underlying contractual logic. In residential apartment buildings, tax subsidies strongly encourage owner-occupancy although, in general, rental is probably the more efficient contractual regime. Conversely, in multiunit commercial buildings the tax law has (at least until 1986) favored rental, although the need of many commercial tenants to customize their space suggests that a regime with many of the attributes of occupant ownership might often be advantageous.

Not surprisingly, the contractual arrangements employed in residential and commercial settings have adjusted accordingly. In condominiums, there appears to be an increasing trend toward delegation of management to hired management companies; the range of decisions that condominium boards reserve for themselves has been shrinking, presumably to

\footnotetext{
91 See, for example, Rohan \& Reskin, supra note 43, at 3.

${ }^{92}$ For example, some tenants may wish to expand their space into that currently occupied by other tenants, or some tenants may wish the building to be open, heated, and attended at night while others do not.
} 
reduce the costs associated with collective decision making. ${ }^{93}$ This move toward a single decision maker whose interests are in some respects at odds with those of the residents mimics rental to a degree, while maintaining the nominal form of owner-occupancy for tax purposes. ${ }^{94}$

Conversely, commercial leases often have many of the attributes of ownership. They are commonly written for relatively long terms (such as ten years), leave the tenant bearing virtually all the costs of maintaining and remodeling his space, and pass through to him all utility and service charges. The owner of the building frequently agrees to do little more than maintain the shell of the building and, even for this service, commonly takes a rental fee that is indexed for inflation. Thus commercial buildings achieve many of the characteristics of condominiums while retaining the nominal form of a leasehold with its tax benefits. ${ }^{95}$

\section{ImPlications for EFFICIENCY AND Policy}

The evidence assembled above does not suffice to provide an unambiguous explanation for the rapid spread of cooperative and condominium housing in the past two decades. The two factors that appear most important are tax subsidies and organizational innovation. But the relative importance of these two factors is unclear. Although the boom in cooperatives and condominiums was preceded by the advent of large net tax subsidies to owner-occupied housing, the sudden surge in cooperatives and, particularly, condominiums in the mid-1970s is difficult to explain on the basis of taxes alone. And, while the latter development might seem to be explained by the adoption of condominium statutes in the early 1960 s, the continuing vitality of the cooperative form in New York City, and the failure of condominiums to achieve much popularity in commercial buildings, both throw some doubt on the significance of the condominium form as a cost-reducing organizational innovation.

${ }^{93}$ In the 1920s there was a similar and apparently successful development involving cooperatives under which, to maintain competent management and avoid tenant disagreements, control of many cooperative buildings was placed in the hands of a self-perpetuating board of trustees. Twentieth Century Fund, supra note 3, at 234-35.

94 This process of cost reduction will undoubtedly continue. For example, one can imagine that the transaction costs of transferring ownership in condominiums could be reduced to the point where they do not appreciably exceed the costs involved in replacing one tenant with another in a rental building. This might be accomplished by having a single bank contract to provide all the mortgage financing for units in a given condominium and work closely with the management company for that building in handling both financing and transfers of title, so that together they would perform some of the role of the conventional landlord who is responsible himself for "lending" all the units in his building to the tenants he selects and repossessing the units in case of nonpayment.

95 Similar tax considerations presumably help explain why leasing of automobiles is common among businesses but rare among individuals. 
One reasonable overall interpretation of the data might be as follows: For all but a small fraction of the occupants of multiunit housing, neither the cooperative nor the condominium form would be competitive with rental in the absence of a tax subsidy. The condominium form, however, is somewhat more efficient than the cooperative form and requires a smaller subsidy to make it competitive with rental. By the mid-1950s, the net tax subsidy to owner-occupancy was sufficiently large to make cooperative housing less expensive than rental for a substantial segment of the population, and this is reflected in the gradually increasing share of the multiunit housing market represented by cooperatives in the $1950 \mathrm{~s}$ and 1960s. Then, in the early 1960s, the condominium form was made available in the United States, largely fortuitously, though perhaps also in part as a response to the stronger demand for owner-occupied apartments generated by the tax subsidy. It subsequently took nearly a decade-until the early $1970 \mathrm{~s}$ - to accumulate sufficient experience with the condominium form to make it acceptable to a broad segment of the market. After that, however, the existing tax subsidy sufficed to induce condominiums to spread rapidly through the housing market.

If this interpretation is roughly correct, it follows that, without a tax subsidy, cooperatives and condominiums might compete poorly with rental in the market for residential apartments and, at least outside of jurisdictions with rent control, might today have a relatively insignificant market share. ${ }^{96}$ This means, in turn, that the tax subsidy to owner-occupied housing may induce substantial inefficiency in the organization of apartment buildings and that a significant fraction of the value of the subsidy may be lost to this inefficiency.

Figure 3 provides an illustration. The vertical axis measures the cost of occupying a given apartment, including transaction costs. The horizontal axis measures the position in the wealth distribution of a given class of households that are otherwise similar in characteristics pertinent to their demand for owner-occupancy versus rental, such as their transiency and their taste for making idiosyncratic alterations in their apartment.

\footnotetext{
\% A substantial fraction of all condominium units (as of 1980, 23 percent) are not occupied by their owners but, rather, are rented out. U.S. Bureau of the Census, 1980 Census of Housing, General Housing Characteristics, United States Summary, ser. HC80-1-A1, table 5. (The reported figures may be misleadingly high, however, because they contain many intrafamily transactions.) This is puzzling in light of the considerations reviewed here. Such an arrangement might seem to get the worst of both worlds: the relatively disadvantageous tax treatment of rental and the collective governance problems of owner-occupancy. It may be, however, that the costs of collective governance are largely avoided by absentee unit owners, who free ride on the efforts of the residents in this regard. Moreover, for many individuals with extra funds to invest, this may have been an easy way to take advantage of the real estate tax shelter, and one lacking the agency problems of a limited partnership.
} 


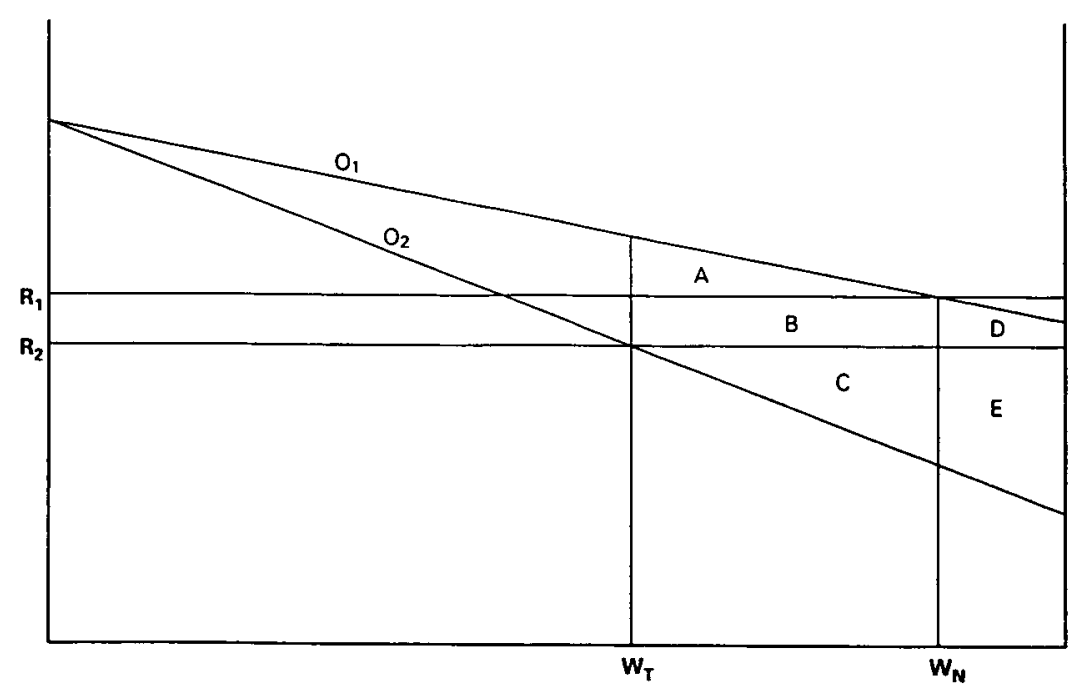

FIGURE 3.-Efficiency and equity consequences of net tax subsidy to owner occupancy

The horizontal line labeled $R_{1}$ gives the cost to such households of renting the apartment in the absence of taxes-a cost that is shown here, as seems roughly reasonable, to be invariant with respect to the household's wealth. The line labeled $R_{2}$ gives the (private) cost of renting the same unit with the subsidy provided to landlords by the real estate tax shelter. (Since 1986, $R_{1}$ and $R_{2}$ would be roughly the same.) The line labeled $O_{1}$ gives the cost of occupying the apartment as an owner-occupant in the absence of taxes; this is assumed to be lower for wealthier households since the latter will (among other things) be less affected by illiquidity and risk. The line labeled $\mathrm{O}_{2}$, in turn, gives the (private) cost of owneroccupancy after taxes. The gap between $O_{1}$ and $O_{2}$ is larger for wealthier households because the exclusion of imputed rental income is more valuable for households in higher tax brackets.

In the absence of taxes, only households higher in the wealth distribution than $W_{N}$ would choose ownership (through a cooperative or condominium); all others would rent. With taxes, however, all households higher in the wealth distribution than $W_{T}$ would choose to own. The total cost of the net tax subsidy to owner-occupancy vis-à-vis rental here is therefore the sum of the areas $A, C$, and $E$. Area $A$ is the efficiency loss from inducing ownership by households for which the social cost of rental is lower, while areas $C$ and $E$ together represent a pure transfer to households that own rather than rent. The efficiency loss represented by area 
$A$ provides another argument-beyond the familiar charges of $(a)$ inequity and $(b)$ encouragement of excessive overall investment in housing $^{97}$-for taxing the imputed rental value of owner-occupied housing or otherwise eliminating the disparity in taxation between rental and ownership. ${ }^{98}$ The magnitude of this efficiency loss depends on the tax bracket of the marginal landlord and of the marginal tenant (that is, the tenant who is just indifferent between renting and owning, with wealth $W_{T}$ in Figure 3). If, for example, the marginal landlord is in the sixtieth percentile or higher and the marginal tenant is between the twentieth and the fiftieth income percentile, then, for 1988, according to Table 7 , part A, the efficiency loss from inducing such a marginal tenant to own rather than rent an apartment is 1.44 percent of the capital cost of the apartment annually, or 16 percent of the cost of rental (which roughly approximates the cost of capital for 1988 since the tax subsidy to rental is essentially gone). If the marginal tenant is in the sixtieth percentile or higher, the efficiency loss is 3.18 percent of the capital cost annually, or 38 percent of the cost of rental. These figures establish an upper bound on the efficiency cost of the subsidy; as Figure 3 shows, inframarginal (wealthier) tenants will experience less inefficiency from owning rather than renting.

\section{Conclusion}

The rapid spread of cooperative and condominium housing over the past three decades offers a striking study in the evolution of legal forms. This development appears to be in part a consequence of organizational innovation and in part a response to tax subsidies. Although it is difficult to sort out the respective contributions of these two factors, the available evidence suggests that tax subsidies may have been more important. In most circumstances, cooperative and condominium housing are evidently less efficient forms of tenure than rental. Without the large tax subsidies of recent decades, cooperative and condominium apartments might well have remained confined principally to jurisdictions with rent control.

Several factors contribute to the costliness of owner-occupancy versus rental in multiunit housing, including illiquidity, poor diversification of risk, and high transaction costs of changing residences. Among the more important of these factors, however, is apparently one that is seldom remarked on, namely the costs of collective governance. Although these costs are low for housing as compared to other consumer goods and services-which helps explain why housing is one of very few nonfinan-

\footnotetext{
97 Yet another argument against the relative subsidy to owner-occupancy is that it encourages underdiversification of investments.

${ }^{98}$ For other means of eliminating the disparity, see note 39 supra.
} 
cial industries in which consumer cooperatives are common ${ }^{99}$ - nevertheless they are evidently sufficiently high to have a significant effect on the market for cooperatives and condominiums.

99 Others are electricity distribution, telephone service, and book retailing. The statement in the text refers to firms owned by individual consumers; consumer cooperatives are far more common among wholesale and supply firms, where the members are the retail firms or producers to whom they sell. See Hansmann, supra note 10. 
